\title{
FROM SARS TO EBOLA: LEGAL AND ETHICAL CONSIDERATIONS FOR MODERN QUARANTINE
}

\author{
Mark A. Rothstein*
}

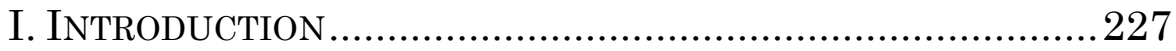

II. A BRIEF HISTORY OF QUARANTINE ..................................229

III. QUARANTINE AND OTHER SOCIAL DISTANCING

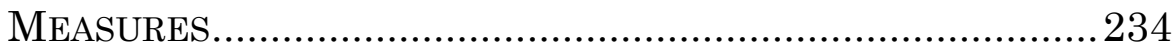

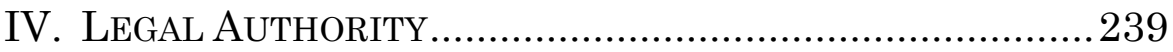

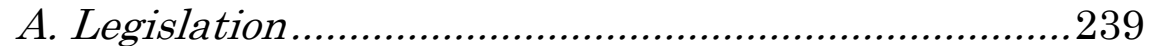

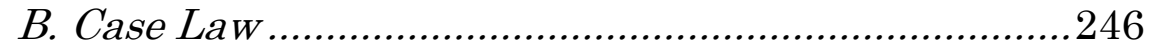

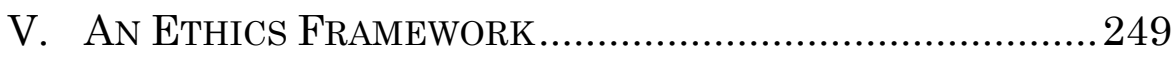

A. Necessity, Effectiveness, and Scientific Rationale ...250

B. Proportionality and Least Infringement .................254

C. Humane Supportive Services ...............................2263

D. Public Justification ..............................................2267

VI. EBOLA QUARANTINE IN LIBERIA ...................................2273

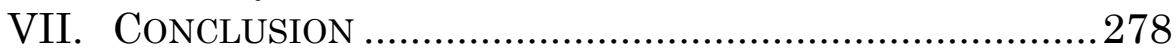

\section{INTRODUCTION}

Quarantine is the restriction of the movement of asymptomatic persons with possible exposure to a communicable disease during its period of communicability to prevent disease transmission. ${ }^{1}$ By contrast, isolation is the separation for the period of communicability of known infected persons to prevent the transmission of the infectious agent. ${ }^{2}$ Quarantine is one of the most aggressive

* Herbert F. Boehl Chair of Law and Medicine and Director, Institute for Bioethics, Health Policy and Law, University of Louisville School of Medicine. Nicholas Craddock, J.D. 2014, provided excellent research assistance.

1 Lawrence O. Gostin, Public Health Law: Power, Duty, RESTRAINT 429 (2d ed. 2008).

$2 I d$. 
and controversial measures public health officials have at their disposal in attempting to control a disease outbreak, because restricting the movement of potentially large numbers of asymptomatic people raises serious legal and ethical concerns. ${ }^{3}$

With the notable exceptions of the Severe Acute Respiratory Syndrome (SARS) outbreak in $2003^{4}$ and the Ebola Virus Disease outbreak in 2014, ${ }^{5}$ quarantine has not been used on a large scale since the first half of the twentieth century. Nevertheless, quarantine remains an important part of the infectious disease containment strategy of the United States and virtually every country. ${ }^{6}$ Therefore, it is appropriate to reflect on the use of quarantine in the past and to explore the legal and ethical considerations for using quarantine in the twenty-first century.

Part II of this article contains a brief history of quarantine. Part III considers various social distancing measures, including voluntary and legally ordered quarantine. Part IV discusses the legal authority for quarantine, including constitutional provisions, statutes, and leading cases. Part V presents an ethics framework for quarantine, emphasizing the following four considerations: (1) necessity, effectiveness, and scientific rationale; (2) proportionality and least infringement; (3) humane supportive services; and (4) public justification. Part VI uses the Ebola quarantine in Liberia as a case study of the dire consequences that follow from a quarantine that fails to

3 See David P. Fidler et al., Through the Quarantine Looking Glass: Drug-Resistant Tuberculosis and Public Health Governance, Law, and Ethics, 35 J.L. MED. \& ETHICs 616, 616 (2007).

4 See Timeline: SARS Outbreak, CNN.com (Apr. 24, 2003, 8:29 $A M)$, archived at http://perma.cc/84TQ-79EX.

5 Compare World HeAlth ORGanization, Ebola Information, archived at http://perma.cc/P7KW-4LUL (stating that fatality rates are 50\%) with WHO Ebola Response Team, Ebola Virus Disease in West Africa - The First 9 Months of the Epidemic and Forward Projections, 371 NEW ENG. J. MED. 1481 (2014) (indicating Ebola case fatality rate is $70.8 \%)$.

6 See Dep't of Health \& Human Servs., HHS Pandemic Influenza Plan (2005), http://www.hhs.gov/pandemicflu/plan/, archived at http://perma.cc/JN59-YGTT/. 
address essential ethical considerations. Part VII concludes by reiterating the significance of ethical considerations in modern quarantine.

\section{A BRIEF History OF QUARANTINE}

The practice of quarantine dates to antiquity. Quarantine for leprosy is mentioned in the Old Testament; 7 quarantine for other diseases was discussed by Hippocrates and other Greek scholars in the fourth century B.C.E. ${ }^{8}$ In the Middle Ages, quarantine probably began in Venice between the twelfth ${ }^{9}$ and fourteenth ${ }^{10}$ centuries, where its name undoubtedly originated. The term "quarantine" is derived from the Italian quaranta giorni, meaning forty days, the time within which it was believed people stricken with the plague would either die or recover and become noninfectious. ${ }^{11}$ Thus, ships arriving in the port of Venice were required to wait at anchor for forty days before unloading their passengers, crew, and cargo. Most experts believe Venice established the first quarantine station, or lazaretto (named after St. Lazarus), on the Island of Santa Maria di Nazareth in the early $1400 \mathrm{~s},{ }^{12}$ although there is some support for the earlier establishment of quarantine

7 Leviticus 14:4-8.

8 HOWARD MARKEL, QUARANTINE! EAST EUROPEAN JEWISH IMMIGRANTS AND THE NEW YORK CITY EPIDEMIC OF 1892 2-3 (1997); Gian Franco Gensini et al., The Concept of Quarantine in History: from Plague to $S A R S, 49$ J. INFECTION 257, 258 (2004).

9 Frank G. Clemow, Origin of Quarantine, 1 BRIT. MED. J. 122, 123 (1929).

10 MARKEL, supra note 8, at 3. But see Eugenia Tognotti, Lessons from the History of Quarantine, from Plague to Influenza A, 19(2) EMERGING INFECTIOUS DISEASES 254, 254 (2013) (asserting that quarantine was first introduced in Dubrovnik in 1377).

11 Fidler et al., supra note 3, at 619. It is not known why forty days was chosen as the length of time for quarantine. Among the theories are that it was derived from Hippocratic theories of illness, Pythagorean numbers theory, and the biblical account of Jesus wandering in the desert for forty years. See Tognotti, supra note 10, at 254. See generally OLEG P. SCHEPIN \& WALDEMAR V. YERMAKOV, INTERNATIONAL QUARANTINE (1991).

12 MARKEL, supra note 8, at 3; Gensini et al., supra note 8, at 259. 
stations. 13 From its origins along the Adriatic coast, quarantine soon became an established public health practice recognized by law throughout Europe. ${ }^{14}$

European legal traditions, as well as diseases, were brought to the American colonies. The earliest law providing for quarantine was enacted by the Massachusetts Bay Colony in 1647 to quarantine ships from the West Indies due to the threat of plague. ${ }^{15}$ The quarantine power was especially important in port cities, such as New York and Boston, where the most common health threats were yellow fever and cholera. ${ }^{16}$ Some cities required medical examinations before passengers could enter. ${ }^{17}$ These local and state quarantine laws predated the drafting of the United States Constitution, ${ }^{18}$ thereby establishing the legal tradition of local and state jurisdiction over matters of public health reflected in the Constitution's reservation of power to the states to regulate public health, safety, and morals. ${ }^{19}$

Initial federal government involvement in quarantine was greatly influenced by the yellow fever epidemic of 1793 , which was so virulent and widespread in the then capital of Philadelphia that it threatened the survival of the nation. ${ }^{20}$ The entire city of Philadelphia was under quarantine, martial law was declared, and residents were prohibited from traveling to other cities, such as Baltimore and New York. ${ }^{21}$ In 1796, Congress enacted the first federal

13 Clemow, supra note 9, at 123.

14 See Paul S. Sehdev, The Origin of Quarantine, 35 CLINICAL INFECTIOUS DisEASES 1071, 1072 (2002).

15 Felice Batlan, Law in the Time of Cholera: Disease, State Power, and Quarantine Past and Future, 80 TEMP. L. REV. 53, 63 (2007).

16 Id. at 64; see also Michael Les Benedict, Contagion and the Constitution: Quarantine Agitation from 1859 to 1866, 25 J. HIST. MED. \& ALLIED SCI. 177, 178 (1970).

17 Batlan, supra note 15 , at 64.

18 See id. at 63.

19 Gibbons v. Ogden, 22 U.S. 1 (1824).

20 See generally Jim MurPhy, An AMERICAN Plague: THE TRUE AND TERRIFYING STORY OF THE YELLOW FEVER EPIDEMIC OF 1793 (2003).

21 See generally J.H. POWELL, BRIng OUT Your DEAD: THE GREAT Plague of Yellow Fever IN Philadelphia IN 1793 (1993). 
quarantine law, which authorized the federal government to assist the states with quarantine. ${ }^{22}$

The federal government sought to expand its quarantine powers after the Civil War, but early laws were weak and met with significant resistance from the states. ${ }^{23}$ In 1878 , Congress enacted the National Quarantine Act, ${ }^{24}$ the first major federal quarantine law, in response to persistent outbreaks of yellow fever along the Mississippi River. ${ }^{25}$ The law created a quarantine division within the Marine Hospital Service and authorized the Surgeon General to issue quarantine regulations that did not conflict with state laws. 26 During the next several years federal laws established quarantine stations, required medical examinations of immigrants, and gave financial incentives to states that used federal quarantine facilities. ${ }^{27}$ In 1944 , Congress enacted the Public Health Service Act, ${ }^{28}$ which consolidated the federal government's quarantine powers over the movement of goods and people in interstate and foreign commerce. The Centers for Disease Control and Prevention (CDC) has been responsible for federal quarantine since 1967.29

Despite its ancient origins, quarantine remains an important tool for public health officials in fighting epidemics. $^{30}$ During the 1918-1919 Spanish flu pandemic,

22 Act of May 27, 1796, ch. 31, 1 Stat. 474 (repealed 1799).

23 Batlan, supra note 15, at 64-65; Les Benedict, supra note 16, at 190-92.

24 Act of June 14, 1879, No. 6, 21 Stat. 50 (1879) (current version at 42 U.S.C. $§ 98$ (2012)).

25 History of Quarantine, CTRS. FOR DisEASE CONTROL AND PREVENTION, http://www.cdc.gov/quarantine/HistoryQuarantine.html, archived at http://perma.cc/2Z8Z-TZVE.

26 Batlan, supra note 15, at 65.

27 Id. at 66-67.

28 Public Health Service Act of 1944, Pub. L. No. 78-410, 58 Stat. 682 (current version at 42 U.S.C. $\S \S 201-300 \mathrm{hh}(2000)$ ).

29 History of Quarantine, supra note 25.

30 See, e.g., E. Delaporte et al., Large Measles Outbreak in Geneva, Switzerland, January to August 2011: Descriptive Epidemiology and Demonstration of Quarantine Effectiveness, 18 EURO. SURVEILLANCE No. 6 (2013), available at http://www.eurosurveillance.org/ ViewArticle.aspx?Articleid=20395, archived at http://perma.cc/A3DL- 
"nonpharmaceutical interventions," including quarantine, were successful in decreasing case fatality rates. ${ }^{31}$ During the SARS epidemic of 2003, quarantine was used extensively in several Asian countries and Canada. In the absence of a vaccine or effective treatment quarantine played a part in ending the epidemic. Similarly, during the Ebola epidemic of 2014 in West Africa, with no vaccine or widely available treatment, and a mortality rate of approximately seventy percent, 32 social distancing measures, including quarantine, became a primary containment strategy. The social distancing measures included school closures and bans on public gatherings, including sports, shopping, and entertainment. ${ }^{33}$ The quarantines were both individually based ${ }^{34}$ and area-wide (or cordon sanitaire). 35

Public health challenges also may be created by quarantine, as illustrated during the SARS epidemic. With several hundred thousand individuals placed in quarantine and relatively few of them later developing SARS, local public health officials later acknowledged that the response was disproportionate to the threat. ${ }^{36}$ Thus, the paradox of quarantine and other social distancing measures is that they may be effective in fighting a disease outbreak, but they can be applied too broadly, resulting in a variety of

KCJ2/; David M. Morens et al., What Is a Pandemic?, 200 J. InfeCtious DisEASES 1018, 1019-20 (2009).

31 Howard Markel et al., Nonpharmaceutical Interventions Implemented by U.S. Cities During the 1918-1919 Influenza Pandemic, 298 JAMA 644, 644 (2007).

32 See World Health ORGanization, supra note 5.

33 Lawrence O. Gostin et al., The Ebola Epidemic: A Global Health Emergency, JAMA, Aug. 11, 2014, archived at http://perma.cc/FZQ5DZS9.

34 Adam Nossiter, Lax Quarantine Undercuts Ebola Fight in Africa, N.Y. Times, Aug. 5, 2014, at A1, archived at http://perma.cc/P5ZNRFG6.

35 Donald G. McNeil, Jr., Using a Tactic Unseen in a Century, Countries Cordon Off Ebola-Racked Areas, N.Y. TIMES, Aug. 12, 2014, at A10, archived at http://perma.cc/VH6C-FS94.

36 See infra text accompanying notes129-130. 
social harms, including economic disruption, personal isolation, and even violence. ${ }^{37}$

Historically, quarantine was a measure borne of scientific uncertainty or outright ignorance. The original forty-day period of quarantine to prevent the spread of the plague bears no relation to the period of incubation for either bubonic (two to ten days) or pneumonic (one to two days) plague, ${ }^{38}$ and it reflects early experience with the disease process of infected individuals. Thus, early social distancing measures often were an ill-defined combination of both quarantine and isolation.

Today, even when evidence of the effectiveness of quarantine is unclear, public health or elected officials often choose to err on the side of caution and order quarantine. For example, SARS involved a previously unknown pathogen with an originally unclear etiology and limited therapeutic options. Under these circumstances an aggressive public health response was predictable. "The impulse for aggressive quarantine is, of course, greatest for those contagious diseases whose terms of transmission remain poorly understood. Any and all precautions against its spread seem reasonable during such crises." ${ }^{39}$ Yet, as discussed below, a public health or government official's "aggressive impulse" sometimes can be counterproductive to

37 Norimitsu Onishi, Clashes Erupt as Liberia Sets a Quarantine, N.Y. TIMES, Aug. 21, 2014 at A1, archived at http://perma.cc/T2TNZA5J.

38 MARKEL, supra note 8, at 198 n.10. There are three types of plague: bubonic, pneumonic, and septicemic. All three are caused by the bacterium Yersinia pestis. Bubonic plague is caused by the bites of fleas that live on small rodents and other animals. The infection enters through the skin and travels through the lymphatic system. Pneumonic plague is a rarer and more lethal form of the infection, which may be spread from human-to-human by inhalation of infected droplets. Untreated, pneumonic plague causes a respiratory infection with an extremely high mortality rate. Septicemic plague, which manifests as a deadly infection of the blood, may be spread through flea bites or handling infected animals. Plague, CTRS. FOR DisEASE CONTROL AND PREVENTION, www.cdc.gov/plague/symptoms, archived at http://perma.cc/WB2A-XR8B.

39 MARKEL, supra note 8, at 48. 
achieving public health goals in responding to an emergency.

This brief excursion into the history of quarantine illustrates three points of continuing importance: (1) quarantine is a long-standing public health intervention that was originally used - and still may be used - when medical countermeasures are unknown, ineffective, or unavailable; (2) in the United States, quarantine began at the local and state level, which is still the practice today, although there is a federal role in coordination, technical support, and prevention of the interstate and international spread of contagion; and (3) although quarantine remains an effective measure, because of its significant implications for civil liberties, economic activity, and social cohesion officials must exercise great care not to overuse their quarantine powers.

\section{QUARANTINE AND OTHER SOCIAL DISTANCING MEASURES}

Outbreaks of the most pathogenic infectious diseases, such as the 1918-1919 Spanish flu, ${ }^{40}$ often spread through close contact, 41 and therefore several public health measures have been used to limit such contact. These measures include not only quarantine, but closing public facilities, especially schools, and canceling events attended by groups or large numbers of people. ${ }^{42}$ "Social distancing" is the modern term applied to various mandatory and recommended strategies to limit close contact. ${ }^{43}$

40 John M. BARry, The Great Influenza: The Story of THE DEAdLIEST PANDEMIC IN History 345, 359 (2004).

${ }^{41}$ Robert J. Glass et al., Targeted Social Distancing Design for Pandemic Influenza, 12 Emerging Infectious Diseases 1671, 1671 (2006).

42 See id. at 1675.

43 See id. at 1671. 


Social Distancing Measures
Cordon sanitaire (area quarantine): The
limitation of entry into or out of a geographic
area where a contagious disease exists. These
measures have been rarely used in the United
States, a notable exception being in Chinatown
in San Francisco in 1900. Cordon sanitaire was
used more extensively in China during the
SARS epidemic and in Liberia during the
Ebola epidemic.
Isolation: The separation, for the period of
communicability, of known infected persons to
prevent the transmission of the infectious
agent. Isolation is easier to justify and enforce
than quarantine because it usually involves
smaller numbers of individuals and people
with symptoms are generally willing to be
isolated for treatment.
Quarantine: Restricting the activities or
movement of asymptomatic individuals who
may have been exposed to a communicable
disease for the duration of the period of
communicability.
Shelter in place: A generally nonmandatory
effort to limit personal exposure in a community
by asking individuals to remain in their homes,
schools, or work locations while a threat exists.
This is also referred to as a "snow day."
Work quarantine: An attempt to deal with
health care worker staff shortages during
epidemics, it asks or perhaps requires health
care workers to work in certain hospital units
while wearing recommended personal
protective equipment. They also should
maintain standard quarantine procedures at
home and avoid public transportation. 4

44 Gene W. Matthews et al., Legal Authorities for Interventions in Public Health Emergencies, in LaW In Public Health Practice 272 (Richard A. Goodman et al. eds., 2d ed. 2007). 
Of the social distancing measures, quarantine is the most intrusive upon individual liberty and therefore raises the greatest number of ethical, legal, and policy issues. Quarantine may involve large numbers of asymptomatic individuals sequestered in their homes or other locations, either voluntarily or pursuant to a legal order. For the duration of the quarantine, ranging from a few days to a few weeks, quarantined individuals are unable to work, attend school, or maintain their normal social interactions. 45 Family members may be separated and individuals may be forced to cope with an extremely stressful situation during the quarantine. Furthermore, individuals may have difficulty adjusting after the quarantine has ended. ${ }^{46}$ Quarantine also can be extraordinarily disruptive on a societal basis, and it may cause, among other things, severe economic disruptions. ${ }^{47}$

Although the impulse of many public health officials is to quarantine every possible at-risk individual, as a scientific matter, it is not necessary to quarantine all or nearly all potentially exposed individuals. The initial purpose of quarantine is to slow the number of new infections to below the total number of deaths plus the total number of people who have recovered in a discrete period of time. To be successful, it is not necessary for a quarantine to eliminate all new cases immediately. Thus, even a "leaky quarantine" is valuable and has utility in the public health response to an epidemic. ${ }^{48}$ Moreover, limiting the number of people subject to quarantine minimizes the individual, economic, and societal disruption of the epidemic and furthers the essential policy of maintaining public support for public health measures, as well as fostering social solidarity.

Quarantine strategy should be flexible and tailored to the specific nature of the public health threat. In the

45 See generally Laura Hawryluck et al., SARS Control and Psychological Effects of Quarantine, Toronto, Canada, 10 EMERGING INFECTIOUS DISEASES 1206 (2004).

46 Id. at 1210.

47 See Lawrence O. Gostin \& Benjamin E. Berkman, Pandemic Influenza: Ethics, Law and the Public's Health, 59 ADMIN. L. REV. 121, 169 (2007).

48 Matthews et al., supra note 44, at 272. 
context of influenza, Dr. Martin Cetron, Director of the CDC's Division of Global Migration and Quarantine, and Dr. Julius Landwirth of the Yale Interdisciplinary Center for Bioethics, advised:

[A]t a stage when transmission of a novel influenza virus is still limited, either abroad or in the area, and local cases are either imported or have clear epidemiological links to other cases, individual quarantine of close contacts may be effective. At a more advanced stage of the pandemic, however, when virus transmission in the area is sustained and epidemiological links to other cases is unclear, limiting quarantine to exposed individuals may be ineffective, and the strategy may need to expand to include community-based interventions that increase social distance. These include school closings, cancellation of public gatherings, encouraging non-essential workers to stay home, and reduced holiday transportation schedules. If these measures are believed to be ineffective, community-wide quarantine may need to be implemented. ${ }^{49}$

Quarantine and other social distancing measures may be voluntary or legally mandated. Voluntary quarantine has some important advantages over mandatory quarantine. Voluntary measures are less coercive for individuals and families; 50 they also place fewer demands on public health agencies, the courts, and law enforcement to obtain and enforce quarantine orders. ${ }^{51}$ Voluntary quarantine also eliminates possible claims of governmental overreaching or

49 Martin Cetron \& Julius Landwirth, Public Health and Ethical Considerations in Planning for Quarantine, 78 YALE J. Biology \& MED. 325, 326 (2005).

50 Ross Upshur, The Ethics of Quarantine, 5 VirTUal Mentor 1, 13 (2003).

51 See Lawrence O. Gostin et al., Quarantine: Voluntary or Not?, 32 J.L. MED. \& ETHICS 83, 83-84 (2004). 
discriminatory enforcement, thereby helping to maintain public support during a time of societal stress or calamity. ${ }^{52}$ On the other hand, it is not clear whether compliance rates for voluntary quarantine are equivalent to those for mandatory quarantine. ${ }^{53}$

Typically, voluntary quarantine is recommended by an authorized public health official who announces a declaration, guideline, or request that a certain group of individuals (e.g., people in a high-risk group, a certain geographic area, or those with possible disease exposure) remain at home or at designated areas for a specific period of time. The announcement also usually provides information about the symptoms of the disease to be monitored, where to go and what to do if symptoms appear, and what public services are available to aid individuals in quarantine. These services include food, medications, other supplies, and information about control of the disease.

By contrast, a mandatory quarantine is more strictly governed by laws and regulations setting out the authority of public health officials and other government authorities. It is more explicit in terms of the procedures and evidence used to reach the decision, the quarantine order's specific applicability, and its duration. Because quarantine often causes hardships and because many Americans are distrustful of the government and are prepared to exercise their legal rights, some quarantine orders are likely to be challenged in court. If the orders are challenged, the contested legal issues may include the statutory authority for quarantine, the burden of proof, the court procedures, and the methods authorized to enforce a quarantine order in the event of noncompliance.

Finally, as noted earlier, quarantine was originally developed as a public health strategy because there was inadequate knowledge about which individuals were exposed to the infectious agent; of those exposed, which individuals were most likely to become infected; and of those infected, which were most likely to recover or to become seriously ill or die. New technologies, especially

52 See Upshur, supra note 50, at 1-3.

53 Gostin et al., supra note 51, at 83. 
those based on genomics, in the reasonably foreseeable future might provide additional information, such as individual genetic susceptibility to particular infections, likely positive or adverse responses to vaccine, likelihood of infecting other individuals, likely response to possible treatment, and expected severity of illness. ${ }^{54}$ These emerging developments in "personalized medicine" raise the prospect of a new, individually based, public health paradigm for resource allocation, prevention, treatment, and containment - including quarantine - to protect the health of the public. ${ }^{55}$ The further exploration of these issues is beyond the scope of this article.

\section{LEGAL AUTHORITY}

\section{A. Legislation}

Primary responsibility for public health policy, funding, staffing, and enforcement is vested in the states. ${ }^{56}$ Each state has its own public health act authorizing state government officials and health department personnel to take specified measures to protect the health and safety of the public. ${ }^{57}$ In every state these measures are authorized pursuant to the state's police powers. 58 The actions include quarantine and isolation, vaccination, disease reporting, travel restrictions, contact tracing, medical examination and treatment, and property seizures. In the event of a public health emergency involving a communicable disease,

54 See, e.g., Jonathan A. Eisen \& Catriona J. MacCallum, Genomics of Emerging Infectious Disease: A PLoS Collection, 7 PLOS BIOLOGY 1, (Oct. 2009), archived at http://perma.cc/E2G5-2ZM8/.

55 See, e.g., Genetics and Public Health in the 21 ${ }^{\text {st }}$ Century: Using Genetic Information to Improve Health and Prevent DISEASE (Muin J. Khoury et al. eds., 2000).

56 Gostin, supra note 1, at 91.

57 State Quarantine and Isolation Statutes, NAT'L CONFERENCE OF STATE LEGISLATURES, www.ncsl.org/issues-research/health/statequarantine-and-isolation-statutes.aspx, archived at http://perma.cc/9FFZ-GZJ2.

58 Gostin, supra note 1, at 95. See Jacobson v. Massachusetts, 197 U.S. 11 (1905) (upholding mandatory smallpox vaccination under state police powers). 
state public health officials working with their local counterparts are responsible for determining whether and how to impose quarantine in accordance with the substantive and procedural requirements of state law. In most states, the authority to use quarantine and similar measures begins when the governor or other public official declares a public health emergency.

After the events of September 11, 2001 and the anthrax incidents that followed shortly thereafter, public concern about the country's vulnerability to bioterrorism provided the impetus to update and revise state public health laws. Many of these laws, including their quarantine provisions, were enacted at the turn of the twentieth century. With support from the CDC, Professor Lawrence Gostin of Georgetown University Law Center led the drafting of the Model State Emergency Health Powers Act (MSEHPA).59 The MSEHPA combined provisions from some noteworthy state statutes and supplemented them with measures to address modern emergencies, including bioterrorism.

The states responded positively to the MSEHPA. By 2006, a total of 171 bills or resolutions were introduced into forty-four states and the District of Columbia that included provisions based on the MSEHPA. 60 Of these bills, sixty-six were enacted in thirty-eight states and the District of Columbia. ${ }^{61}$ Because the MSEHPA was based on provisions of existing state laws it is difficult to say precisely how many provisions were adopted from the MSEHPA. Only Louisiana and South Carolina made wholesale adoptions of provisions from the model act. ${ }^{62}$

59 Model State Emergency Health Powers ACt (2001), available at http://www.publichealthlaw.net/Resources/Modellaws.htm\#MSEHPA, archived at http://perma.cc/22BG-WEEP/ (last visited Feb. 8, 2014).

60 The Model State Emergency Health Powers Act (MSEHPA) State Legislative Activity, CTR. FOR LAW \& Pub. Health at GeORgetown \& JOHNS HOPKINS UNIVS. http://www.publichealthlaw.net/ MSEHPA/MSEHPA\%20Leg\%20Activity.pdf, archived at http://perma.cc/RQP3-RDC8.

61 Id.

62 The Model State Emergency Health Powers Act Summary Matrix, THE NETWORK FOR PUB. HEAlTH LAW, https://www.networkforphl.org/_asset/80p3y7/Western-Region- 
Sections 604 and 605 of the MSEHPA deal with isolation and quarantine. Among other provisions, the MSEHPA provides that isolation and quarantine "must be by the least restrictive means," ${ }^{63}$ for the minimum time necessary, ${ }^{64}$ and provide "adequate food, clothing, shelter, means of communication with those in isolation or quarantine and outside of those settings, medication, and competent medical care." 65

Procedures for isolation and quarantine put an emphasis on responding to public health emergencies quickly. For example, the MSEHPA permits the isolation and quarantine of individuals without notice for up to ten days pursuant to an administrative directive, ${ }^{66}$ as well as a court order. ${ }^{67}$ Notice of a judicial petition for an isolation or quarantine order must be given to affected individuals or groups within twenty-four hours, ${ }^{68}$ and hearings based on such a petition must be held within five days. 69 The judicial procedures of the MSEHPA demonstrate why voluntary quarantine is much better than an administrative or courtordered quarantine. Among the drawbacks to mandatory quarantine are the need for public health departments to devote essential resources to litigation in a time of emergency, the lack of familiarity of trial court judges with the scientific issues in a quarantine petition, the reluctance of many court personnel to attend a hearing involving deadly and communicable pathogens and the lack of procedures or technology for ex parte hearings, the inability of many court systems to process timely appeals, and the nagging issue of how to deal with individuals who fail to comply with a court-ordered quarantine. ${ }^{70}$

MSEHPA-States-Table-8-10-12.pdf, archived at http://perma.cc/E8YZ9VQE/ (last updated June 2012).

63 The Model State Emergency Health Powers Act § 604(b)(1) (2001).

64 Id. $\S 604(\mathrm{~b})(4)$.

65 Id. $\S 604(\mathrm{~b})(6)$.

66 Id. $\S 605(\mathrm{a})$.

$67 I d . \S 605(\mathrm{~b})$.

68 Id. $\S 605(\mathrm{~b})(3)$.

69 Id. $\S 605(\mathrm{~b})(4)$.

70 See infra notes 181-183 and accompanying text. 
Although the MSEHPA was designed to provide clearer standards and stronger guarantees of due process, it has been criticized for failing to provide adequate protection for civil liberties and dispensing with the legal rights of some individuals. ${ }^{71}$ For example, the MSEHPA grants states the authority to isolate individuals who refuse vaccination during a public health emergency. ${ }^{72}$ In addition, under the MSEHPA out-of-state emergency health care providers are immune from liability for damages caused by negligent treatment "unless such damages result from providing or failing to provide, medical care or treatment under circumstances demonstrating a reckless disregard for the consequences so as to affect the life or health of the patient." 73 Nevertheless, there have not been any medical malpractice cases arising from volunteer treatment in a public health emergency, and there is little evidence that malpractice immunity is necessary to attract volunteer health care providers. ${ }^{74}$ Finally, the MSEHPA provides for the courts to use the preponderance of the evidence standard. ${ }^{75}$

${ }^{71}$ George J. Annas, Blinded by Bioterrorism: Public Health and Liberty in the 21st Century, 13 HEALTH MatriX 33, 45-54 (2003); George J. Annas, Bioterrorism, Public Health, and Civil Liberties, 346 NEW EnG. J. MED. 1337, 1338-39 (2002); Wendy E. Parmet, Quarantine Redux: Bioterrorism, AIDS, and the Curtailment of Individual Liberty in the Name of Public Health, 13 Health Matrix 85, 86-87 (2003). See also Lawrence O. Gostin, The Model State Emergency Health Powers Act: Public Health and Civil Liberties in a Time of Terrorism, 13 Health MatriX 3, 5 (2003) ("Despite its success in many states, the Model Act has become a lightning rod for criticism from both ends of the political spectrum.").

72 The Model State Emergency Health Powers ACt $§$ 603(a)(3) (2001).

73 Id. $\S 608(\mathrm{~b})(3)$.

74 See Mark A. Rothstein, Malpractice Immunity for Volunteer Physicians in Public Health Emergencies - Adding Insult to Injury, 38 J.L. MED. \& ETHICS 149 (2010) (asserting that dividing patients into paying customers who retain all of their legal rights and indigent customers who lose certain legal rights is unnecessary and further stigmatizes a vulnerable group at a time when social solidarity is of utmost importance to public health).

75 The Model State Emergency Health Powers ACt § 605(e) (2001). Notably, the Turning Point Model State Public Health Act 
Another model law project, this one supported by the Robert Wood Johnson Foundation, the Turning Point Model State Public Health Act (TPMSPHA), ${ }^{76}$ addressed an even broader array of public health issues, not just those arising in emergencies. Article V of the TPMSPHA dealing with Authorities/Powers is where the quarantine and isolation provisions appear. The following eight conditions and principles apply to isolation and quarantine: (1) isolation and quarantine must use the least restrictive means necessary; (2) isolated individuals must be kept separately from quarantined individuals; (3) the health status of individuals in isolation and quarantine must be monitored regularly; (4) an individual in quarantine who becomes infected must be removed promptly to isolation; (5) isolation and quarantine must be terminated immediately when an individual no longer poses a substantial risk of transmitting an infection; (6) individuals must be supplied with adequate food, clothing, shelter, a means of communication, and competent medical care; (7) outside premises used for isolation and quarantine must be maintained in a safe and hygienic manner; and (8) to the extent possible, cultural and religious beliefs shall be respected. 77

The TPMSPHA provides for quarantine and isolation with notice ${ }^{78}$ and without notice. ${ }^{79}$ Quarantine and isolation without notice is permitted only if notice "would significantly jeopardize the agency's ability to prevent or limit the transmission of a contagious or possibly contagious disease to others." 80 The TPMSPHA provides for prompt hearings; the government must appoint counsel without

section 5-108[e](4) uses the "clear and convincing evidence" standard for quarantine orders. See The Turning Point Model State Public HEALTH ACT (2003), available at http://www.publichealthlaw.net/ModelLaws/MSPHA.php, archived at http://perma.cc/H2AK-MSD2.

76 The Turning Point Model State Public Health Act, supra note 75 .

77 Id. $\S 5-108[\mathrm{~b}]$.

78 Id. $\S 5-108[\mathrm{e}]$.

79 Id. $\S 5-108[\mathrm{~d}]$.

$80 \mathrm{Id}$. 
charge to those subject to quarantine. 81 Elements of the TPMSPHA have been adopted, at least in part, by over half of the states. ${ }^{82}$ Thus, many states have adopted provisions of both the MSEHPA and the TPMSPHA.

The federal government, specifically the Department of Health and Human Services (HHS) and its designated agency, the CDC, also has limited authority to impose quarantine. This authority, pursuant to section 361(b) of the Public Health Service Act (PHSA), 83 is restricted to preventing communicable diseases from entering the country or crossing state lines. ${ }^{84}$ To do so, as of 2015 , the CDC has twenty quarantine stations at points of entry and land border crossings, which represents a significant increase from the eight stations in place during the SARS outbreak of 2003.85 During the Ebola epidemic in 2014, CDC personnel at the airport quarantine stations screened international passengers in attempting to prevent the spread of infection. Section 361(d) of the PHSA also authorizes the Surgeon General to isolate individuals with a communicable disease who attempt to cross-state or national borders. ${ }^{86}$

The PHSA lists the following diseases for possible quarantine: cholera, diphtheria, infectious tuberculosis, plague, smallpox, viral hemorrhagic fever, and yellow fever. ${ }^{87}$ Pursuant to Executive Orders in 2003 and 2005, the following conditions were added: SARS and "influenza viruses that are causing, or have the potential to cause, a

81 Id. $\S 5-108[\mathrm{f}]$.

82 See Gostin, supra note 71, at 5. See also James G. Hodge, Jr., Transforming Public Health Law: The Turning Point Model State Public Health Act, 34 J.L. MED. \& ETHICS 77 (2006).

83 Public Health Service Act of 1944, Pub. L. No. 78-410, § 361(b), 58 Stat. 682 (codified as amended at 42 U.S.C. § 264(b) (2012)). See 42 C.F.R. Parts 70, 71 (2014).

8442 U.S.C. $\S 264(\mathrm{~b})$.

85 Inst. OF Med., Quarantine Stations at Ports of Entry: Protecting the Public's Health (Laura B. Sivitz et al., eds. 2005), available at http://www.nap.edu/openbook.php?record_id=11435 (last visited Feb. 17, 2015).

86 Public Health Service Act of 1944, Pub. L. No. 78-410, § 361(d), 58 Stat. 682 (codified as amended at 42 U.S.C. $\S 264(d)$ ).

8742 U.S.C. $§ 264(b)$ (2014). 
pandemic." 88 On July 31, 2014, President Obama amended the executive orders to clarify their applicability. The new language reads as follows:

(b) Severe acute respiratory syndromes, which are diseases that are associated with fever and signs and symptoms of pneumonia or other respiratory illness, are capable of being transmitted from person to person, and that either are causing, or have the potential to cause, a pandemic, or, upon infection, are highly likely to cause mortality or serious morbidity if not properly controlled. This subsection does not apply to influenza. ${ }^{89}$

The CDC has separate quarantine regulations for interstate 90 and foreign 91 quarantine. The regulations authorize the detention, isolation, quarantine, or conditional release of individuals for the purpose of preventing the introduction and spread of the communicable diseases listed in the executive orders. ${ }^{92}$ Besides this limited quarantine authority, the CDC plays an important role in research, education, laboratory services, funding, data gathering, and other matters affecting emergency preparedness and the control of communicable diseases.

The decentralized and fragmented nature of American public health law presents great challenges for coordination among federal, state, and local officials as well as among various agencies and private entities. During the 2014 Ebola outbreak, the initial handling of Thomas Eric Duncan

88 Exec. Order No. 13,295, 68 Fed. Reg. 17,255 (Apr. 4, 2003); Exec. Order No. 13,375, 70 Fed. Reg. 17,299 (Apr. 1, 2005).

89 Exec. Order No. 13674, 79 Fed. Reg. 45,671 (Jul. 31, 2014) The reason this clarification may be helpful is that the initial symptoms of Ebola are influenza-like respiratory involvement. The classic hemorrhagic fever symptoms occur later. See World Health Organization, supra note 5.

9042 C.F.R. pt. 70 (2014).

9142 C.F.R. pt. 71 (2014).

9242 C.F.R. $\S 70.6$ (2013). 
by Texas Health Presbyterian Hospital in Dallas is a case in point. At his initial emergency department visit, Mr. Duncan disclosed that he had recently arrived from Liberia, but the information was not received by the examining physicians, who failed to follow-up about his recent travels. This lack of communication or follow-through permitted the index case of Ebola in the United States to be misdiagnosed as sinusitis, and Mr. Duncan was discharged with only a prescription for antibiotics. ${ }^{93}$ Later, the lack of coordination of hazardous waste removal between local public health officials and federal licensing authorities delayed the removal of soiled clothing, bedding, and linens from the apartment where he was staying and where relatives were later quarantined. ${ }^{94}$ The enactment of appropriate legislation is only the first step in an effective public health response to infectious disease outbreaks; the laws must be implemented efficiently to achieve the desired results.

\section{B. Case Law}

The United States Supreme Court has explicitly upheld the exercise of broad quarantine powers by the states. In the leading case of Compagnie Francaise de Navigation a Vapeur v. Louisiana State Board of Health ${ }^{95}$ the Louisiana Board of Health imposed a cordon sanitaire on seven parishes in the state, including Orleans Parish, because of the presence of an unspecified epidemic. ${ }^{96}$ In theory, the restriction applied to all individuals attempting to enter or leave any of the seven parishes, but it was alleged in the lawsuit challenging the action that the restriction was adopted and applied only to the 408 Italian immigrants on the French ship Britannia who were attempting to land in New Orleans. ${ }^{97}$ The Supreme Court upheld the power of the state to enforce quarantine laws in the absence of a contrary federal law, thereby rejecting claims that the State

${ }^{93}$ Ana Campoy et al., U.S. Tries to Calm Public on Ebola, Wall St. J., Oct. 4-5, 2014, at A1, A6.

${ }_{94} I d$.

95186 U.S. 380 (1902).

96 See id. at 381-82.

97 Id. at 382. 
of Louisiana lacked the authority to regulate international commerce and that the statute violated international treaties. ${ }^{98}$ Perhaps because the case was brought by the steamship company (seeking to recover the cost of caring for the passengers during the quarantine) and not the passengers, neither the majority nor the dissent addressed possible violations of the Equal Protection Clause of the Fourteenth Amendment in applying the law only to immigrants on one ship. 99

Because of the severe limitations on individual liberty resulting from quarantine, even the older cases have focused on whether procedural requirements were followed. For example, in State v. Kirby, ${ }^{100}$ an individual who was in quarantine for smallpox left confinement without the permission of the authorities. In a subsequent criminal prosecution for violating quarantine the Iowa Supreme Court noted that the statute required government officials to provide notice of the quarantine to the individual. Because there had been no notice the conviction was reversed.

In Ex parte Culver, ${ }^{101}$ a habeas corpus petition was filed after the defendant was convicted of a misdemeanor in connection with a quarantine. The defendant's niece was in a quarantined premises for diphtheria, and the crime was removing, in the presence of a police officer, the health department placard stating that the premises was subject to quarantine. In affirming the conviction, the California Supreme Court emphasized the broad powers granted to state officials under the public health act when it held that:

There can be no doubt but that ... the state board of health has power to order the quarantine of persons who have come in contact with cases and carriers of contagious diseases whenever in the judgment of the said

\footnotetext{
$98 \quad I d$. at 397.

99 See id. at 381.

10094 N.W. 254 (Iowa 1903).

101202 P. 661 (Cal. 1921).
} 
board such action shall be deemed necessary to protect and preserve the public health. ${ }^{102}$

More recent state court decisions also have upheld the authority of public health officials to confine individuals to prevent the transmission of infectious disease as long as certain criteria have been met. For example, in Greene v. Edwards, 103 an individual with "active communicable tuberculosis" was confined in a state hospital pursuant to a state statute. 104 The West Virginia Supreme Court of Appeals stayed the individual's confinement, granted the individual a new hearing regarding his confinement, and held that due process guaranteed the individual a hearing with the following procedures: (1) written notice; (2) right to counsel; (3) right to be present, and to cross-examine, confront, and present witnesses; (4) standard of proof of clear, cogent, and convincing evidence; and (5) right to a transcript for purposes of appeal. 105 Without the timely appointment of counsel, the Greene court decided that not all of the constitutional safeguards had been met, and that a new hearing was required. ${ }^{106}$ It is not clear to what degree these rights would apply to quarantine at home (as opposed to isolation in a state hospital) and possibly larger-scale, but shorter-term confinement rather than for treatment of tuberculosis.

Other state court decisions have agreed with the rationale of the Greene case and upheld state-imposed isolation of individuals with tuberculosis so long as procedural requirements were followed. ${ }^{107}$ The wording of the state statute authorizing the confinement is very important. In City of Milwaukee v. Washington, 108 a homeless woman violated a court order to appear for

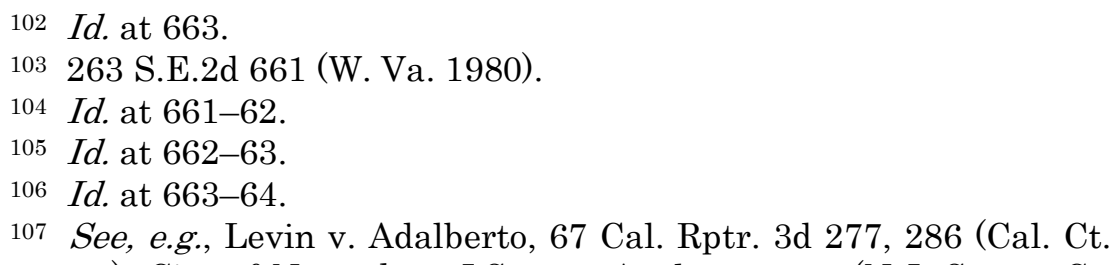
App. 2007); City of Newark v. J.S., 652 A.2d 265, 278 (N.J. Super. Ct. Law Div. 1993).

108735 N.W.2d 111 (Wis. 2007). 
treatment and monitoring of her tuberculosis. 109 When she was located and sent to a correctional facility for her period of isolation, she objected and said she should be sent to a hospital, instead. 110 The Wisconsin Supreme Court interpreted the relevant state statute providing for use of the "least restrictive" alternative to quarantine or isolation to mean that confinement had to be the least restrictive method of social distancing, not that the confinement had to be in the least restrictive facility. ${ }^{111}$ By contrast, in Souvannarath v. Hadden, ${ }^{112}$ the court did not allow for the imprisonment of a tuberculosis patient because the applicable California statute expressly provided that individuals quarantined or isolated for tuberculosis "shall not" be placed in a correctional facility. ${ }^{113}$

\section{AN Ethics Framework}

The ethical basis of public health is utilitarianism. ${ }^{114}$ Efforts to prevent catastrophic diseases and alleviate mass suffering provide a broad justification for infringing on the rights of some members of the public through quarantine, property seizure, vaccination mandates, or other public health measures. Utilitarian concerns about maximizing benefits, however, are not a blank check for public health interventions. In the United States, with its strong libertarian tradition and its commitment to autonomy, justice, and procedural due process, the exercise of public health authority always must be preceded by a showing of necessity, minimal infringement on individual rights, and essential procedural due process.

In resolving the invariable conflict between utilitarianism and libertarianism, Professor James Childress and colleagues have suggested there are five

109 Id. at 114.

110 Id.

111 See id. at 128-29.

112116 Cal. Rptr. 2d 7 (Cal. Ct. App. 2002).

113 Id. at 13.

114 Antoon Hubert \& Marie Kerkhoff, Origin of Modern Public Health and Preventive Medicine, in Ethical Dilemmas In Health Promotion (Spyros Doxiadis, ed. 1987). 
"justificatory conditions" that help determine "whether promoting public health warrants overriding such values as individual liberty or justice in particular cases." 115 According to this general formulation, the justificatory conditions are effectiveness, proportionality, necessity, least infringement, and public justification. ${ }^{116}$

Although quarantine may be viewed as the paradigmatic case for balancing individual and communal interests, quarantine also can be regarded as sui generis because of the extreme limits it places on liberty. Therefore, quarantine requires its own analytical framework. Adapting from the typology of Childress et al., the following four ethical considerations discussed below should be evaluated in deciding whether to order a quarantine and, if so, the specifics of quarantine. The ethical considerations are: (1) necessity, effectiveness, and scientific rationale; (2) proportionality and least infringement; (3) humane supportive services; and (4) public justification. ${ }^{117}$

\section{A. Necessity, Effectiveness, and Scientific Rationale}

"Necessity" means public health officials ought to impose quarantine only in the face of a demonstrable threat to public health. 118 The use of quarantine is based on the assumption that asymptomatic individuals exposed to an infection are capable of transmitting the infection to others, perhaps as efficiently as symptomatic individuals. In addition to individual quarantine, area-wide quarantine may be an effective way of limiting the spread of the

115 James F. Childress et al., Public Health Ethics: Mapping the Terrain, 30 J.L. MED. \& ETHICs 170, 172 (2002). See also Nancy E. Kass, An Ethics Framework for Public Health, 91 AM. J. Pub. HeALth 1776 (2001).

116 Id.

117 There are several other formulations of principles for quarantine. Many of them have similar emphasis. See, e.g., Ross E.G. Upshur, Principles for the Justification of Public Health Intervention, 93 CAN. J. Pub. Health 101, 102-03 (2002) (proposing the following principles: (1) necessity, (2) least restrictive means, (3) necessary support services, and (4) communication of reasons).

118 Gostin \& Berkman, supra note 47, at 147. 
disease. The potential effectiveness of quarantine is related to the interval between exposure and the onset of illness. For infections with a short interval, such as the one to four days for influenza, there may be a narrower window to impose quarantine. ${ }^{119}$ For Ebola, with a two to twenty-one day incubation period, a longer quarantine has been used; indeed, the long quarantine period has been associated with many problems in Liberia and the United States. ${ }^{120}$

Regardless of the specifics, quarantine has been successful in various settings, from decreasing fatality rates in the Spanish flu pandemic ${ }^{121}$ to reducing transmission of a more recent measles outbreak. ${ }^{122}$ For SARS, there was a presumptive ten-day period between exposure and symptoms. ${ }^{123}$ Although halting the spread of SARS justified some quarantine, the relatively low rate of transmissibility of the causative coronavirus by asymptomatic individuals lessened the need for and the efficacy of large-scale quarantine. ${ }^{124}$

As with any public health measure, quarantine should not be invoked unless the best available scientific evidence indicates it is necessary and likely to be effective in controlling the epidemic. ${ }^{125}$ Unfortunately, it is rarely possible to make precise calculations of necessity and efficacy in advance of imposing quarantine. Thus, social distancing measures should be adopted that balance the degree of coercion with the expected benefit. ${ }^{126}$ In some

119 Lawrence O. Gostin, Public Health Strategies for Pandemic Influenza: Ethics and the Law, 295 JAMA 1700, 1703 (2006).

120 See Part VI infra.

121 Markel, supra note 31, at 644.

122 See Delaporte, supra note 30.

123 Mark A. Rothstein et al., Quarantine and Isolation: Lessons Learned From SARS: A Report to the Centers for Disease Control and Prevention 23 (2003), available at http://stacks.cdc.gov/view/cdc/11429, archived at http://perma.cc/X4TE-F2PB.

124 See Steven Riley et al., Transmission Dynamics of the Etiological Agent of SARS in Hong Kong: Impact of Public Health Interventions, 300 SCIENCE 1961, 1961 (2003).

125 See Upshur, supra note 117, at 102-03.

${ }^{126}$ CTRs. For Disease CONTROL \& PREVEnTION, ETHICAL Guidelines In PANDEMic Influenza 8 (2007); A.M. Viens et al., Your Liberty or 
public health emergencies, however, government leaders and public health officials have ordered quarantines that were unnecessary and unjustified by the scientific evidence. For example, during the SARS epidemic, India and Thailand quarantined all foreign visitors from countries with SARS outbreaks, even if they had no symptoms or known exposures. ${ }^{127}$ Similarly, during the Ebola epidemic, North Korea imposed a three-week quarantine on travelers entering from every country. ${ }^{128}$

A glaring overuse of individual quarantine occurred in Taiwan during the SARS epidemic, when 131,132 people were placed under home quarantine, but only twelve were found to have potential cases of SARS, and only two had confirmed cases of SARS. ${ }^{129}$ Such unwarranted public health measures can do more than inconvenience the people placed in quarantine. Officials in Taiwan subsequently concluded that the aggressive use of quarantine contributed to public panic and thus proved counterproductive to public health. ${ }^{130}$ This experience should give pause to public health officials before they recommend sweeping quarantine measures without sufficient evidence of necessity and a compelling scientific rationale.

During the Ebola epidemic, the government of Sierra Leone imposed an area-wide quarantine in about one-fourth of the country, affecting over one million people. ${ }^{131}$ Travelers were permitted to travel through quarantine zones only between the hours of 9 a.m. and 5 p.m., and they were warned not to get out of their vehicles while traveling through these areas. ${ }^{132}$ These restrictions came only a week

Your Life: Reciprocity in the Use of Restrictive Measures in the Context of Contagion, 6 J. BIOETHICAL INQUIRY 207, 208 (2009).

127 Rothstein et al., supra note 123, at 128.

128 Choe Sang-Hun, North Korea Said to Impose Ebola Quarantine on All Travelers, N.Y. TIMES, Oct. 31, 2014, at A23, archived at http://perma.cc/W6DF-VTSH.

129 Rothstein et al., supra note 123, at 131 .

130 Id.

131 Adam Nossiter, Ebola Epidemic Worsening, Sierra Leone Expands Quarantine Restrictions, N.Y. TIMES, Sept. 26, 2014, at A16, archived at https://perma.cc/JH9V-FX9X?type=image.

132 Id. 
after a three-day home quarantine of the entire country, in which 30,000 volunteers went house-to-house to educate the public about Ebola and remove the dead. ${ }^{133}$ President Ernest Bai Koroma acknowledged that the new quarantine would "definitely pose great difficulties for our people," but he said there was little choice. ${ }^{134}$

A poorly devised and implemented quarantine may cause great harm. In Sierra Leone, some villages set up informal "isolation centers," with citizens quarantining one another, "an incredibly dangerous ad hoc solution being performed without appropriate protection." ${ }^{135}$ Meanwhile, the lack of hospital beds, ambulances, and safe burial practices continued to spread infection. ${ }^{136}$ According to Anthony Banbury, head of the United Nations Mission for Ebola Emergency Response, up to one-half the deaths in Sierra Leone were caused by unsafe burial practices. ${ }^{137}$

To be effective, a quarantine must be part of a scientifically compelling, overall strategy for battling the outbreak of infectious disease. For example, in Liberia the escalation in Ebola cases was largely due to the lack of hospital space, personal protective equipment, and strict infection control procedures in health care facilities. At the height of the epidemic, only eighteen percent of patients were being cared for in hospitals, well below the seventy percent the CDC estimated would be necessary to prevent

133 Adam Nossiter, Lockdown Begins in Sierra Leone to Battle Ebola, N.Y. Times, Sept. 20, 2014, at A1, archived at http://perma.cc/8BJH-CJ7J; Rukmini Callimachi, Fear of Ebola Drives Mob to Kill Officials, N.Y. TIMES, Sept. 19, 2014, at A15, archived at http://perma.cc/JC9F-BPUS.

134 Nossiter, supra note 131.

135 Jeffrey Gettleman, Despite Aid Push, Ebola Is Raging in Sierra Leone, N.Y. TIMES, Nov. 29, 2014, at A1, A14, archived at http://perma.cc/UY46-P9A6.

136 Id.

137 Doctor Who Died of Ebola Hailed as a Hero, DAILY MAIL (Nov. 29, 2014), archived at http://perma.cc/2Q2M-8YWY. See also Carrie F. Nielsen et al., Improving Burial Practices and Cemetary Management During an Ebola Virus Disease Epidemic -- Sierra Leone, 2014, 64 MORBIDITY \& MORTALITY WEEKLY REP. 20 (2015). 
cases from increasing. ${ }^{138}$ Because of a lack of functioning hospitals, most Ebola patients were cared for at home by relatives and friends who lacked training and infection control materials, thereby spreading the deadly infection to caregivers. The government provided little or no assistance. According to the son of one victim, "The only thing the government can do is come for the bodies. They are killing us." 139

Ebola has been an epidemic overwhelmingly affecting caregivers, both health care workers and family members of patients. According to a study of Ebola in Sierra Leone, the incidence of Ebola in health care workers was 103-fold higher than that of all other individuals in the country. ${ }^{140}$ This study further confirms that the necessity, effectiveness, and scientific rationale of any quarantine are closely related to the epidemiology of the disease outbreak.

\section{B. Proportionality and Least Infringement}

"Proportionality" means the public health response is appropriate in light of the threat; in other words, there is a reasonable relationship between the burdens and the expected benefits. ${ }^{141}$ Not all events of infectious disease requiring social distancing measures justify using quarantine, the most coercive and intrusive measure. On the other hand, shelter in place or other measures may be insufficiently aggressive. For example, during the early days of the Ebola epidemic in West Africa, some governments declared stay-at-home days for "reflection, education, and prayers" as a modest and noncoercive social

138 Norimitsu Onishi, In Liberia, Home Deaths Spread Circle of Contagion, N.Y. TIMES, Sept. 25, 2014, at A1, A6, archived at http://perma.cc/FGT7-YXA9.

139 Id. at A1. Another resident of Liberia similarly remarked: "No one comes when we are sick, only when we are dead." Aryn Baker, Racing Ebola: What the World Needs to Do to Stop the Deadly Virus, TIME, Oct. 13, 2014, at 38, 40.

140 Peter H. Kilmarx et al., Ebola Virus Disease in Health Care Workers - Sierra Leone, 2014, 63 MoRBIDITY \& MORTALITY WEEKLY REP. 1168 (2014).

141 Gostin \& Berkman, supra note 47, at 148. 
distancing measure.142 Similarly, Guinea closed all schools and universities indefinitely. ${ }^{143}$ These measures were ineffective because they were not stringent enough and therefore not proportional to the threat. Later, when the epidemic worsened, some of the quarantine measures were overly aggressive and counterproductive to public health and humanitarian objectives. Public health officials need to strike the right balance in arriving at "proportionality"and this is not easy to do.

When the initial Ebola cases spread to the United States, first in Dallas and then in New York City, public fears caused twenty-one states to impose a mandatory twenty-one-day quarantine of all health care workers returning to the United States after treating Ebola patients in West Africa. ${ }^{144}$ It is very unlikely that these low- $^{-}$to moderate-risk health care workers with "protected exposures" (i.e., they used personal protective equipment and strict infection control measures) needed to be in quarantine instead of self-monitoring. Even assuming some type of social distancing was prudent to prevent transmission of Ebola, imposing such a long period was not supported by the science. The mean incubation period for

142 Gostin et al., supra note 33.

143 Tamba Jean-Matthew, Guinea Postpones Reopening of Schools Due to Ebola, AFRICA REV., Sept. 8, 2014, http:www.africareview.com/ News/Guinea-postpones-reopening-of-schools-due-to-Ebola/979180/2445502/-/wwb4omz/-/index.html.

${ }^{144}$ CDC, Interim Table of State Ebola Screening and Monitoring Policies for Asymptomatic Individuals, $\mathrm{http}: / / \mathrm{www} . c d c . g o v / \mathrm{phlp} /$ docs/interim-ebolascreening.pdf (last visited Feb. 8, 2015); See Marc Santora, First Patient Quarantined Under Strict New Policy Tests Negative for Ebola, N.Y. Times, Oct. 25, 2014, at $\mathrm{A} 1$, archived at http://perma.cc/BW7P-2759 (discussing case of nurse quarantined in N.J.). 
Ebola is eight to ten days, ${ }^{145}$ and very few people become symptomatic after fourteen days. ${ }^{146}$

One consequence of states imposing twenty-one day quarantines was that essential health care workers were dissuaded from volunteering to serve in West Africa. ${ }^{147}$ Other important reasons for questioning these ad hoc state policies include possibly undermining the CDC's credibility and confusing the public by having different quarantine policies in each state. A universally applied twenty-one-day quarantine for all individuals who travelled to West Africa, including members of the armed forces who merely built health care facilities, was neither scientifically indicated nor proportional to the risk. Furthermore, such a long quarantine period increases the burdens on public officials to monitor compliance and to provide food, medicine, and other supportive services.

During the Ebola outbreak, the CDC did not initially recommend quarantine for asymptomatic contacts of Ebola patients whose only exposure to an Ebola patient occurred before the patient had symptoms and became contagious. ${ }^{148}$ The first quarantine order in the United States involving Ebola took place on October 2, 2014, when Texas health officials served a quarantine order on four close family members of the first Ebola case, Thomas Eric Duncan. The order required the family members to remain in their small apartment for an additional seventeen days (for a total of

145 Ebola (Ebola Virus Disease) - Signs and Symptoms, CDC, www.cdc.gov/vhf/ebola/symptoms/index.html (last visited Feb. 10, 2015); See also WHO Ebola Response Team, Ebola Virus Disease in West Africa - The First 9 Months of the Epidemic and Forward Projections, 371 NEW ENG. J. MED. 1481, 1487 (2014) (mean incubation period is 11.4 days).

146 WHO Ebola Response Team supra note 145; see also CDC, INTERIM U.S. GUIDANCE FOR MONITORING AND MOVEMENT OF PERSONS With Potential Ebola Virus Disease Exposure (Dec. 24, 2014), archived at http://perma.cc/6896-Z4KR/ (stating that "risk falls substantially after 2 weeks").

147 Greg Botelho, Should Health Care Workers Who Treat Ebola in Africa Be Quarantined?, CNN (Oct. 26, 2014) http://www.cnn.com/2014/10/24/health/ebola-travel-policy/, archived at http://perma.cc/W9QR-DYSR.

148 CDC, supra note 146. 
twenty-one days post exposure), and to comply with blood tests and other monitoring deemed necessary by public health officials. ${ }^{149}$ Subsequently, the CDC revised its recommendations to provide that all asymptomatic health care workers returning from West Africa should be regarded as having "some risk" of Ebola and therefore required "direct active monitoring" for twenty-one days, with possible additional restrictions on their right to travel freely to be determined on a case-by-case basis by local public health officials. 150

To be effective, any public health response to an infectious disease outbreak depends on the prompt clinical diagnosis of infected persons and the prompt imposition of isolation. In a mere two days, the time between when Mr. Duncan was mistakenly discharged from the hospital's emergency department and the time he was readmitted and placed in isolation, as many as 100 individuals had possible exposure. Counting the contacts of the health care workers who treated him, 177 people in Texas were placed in quarantine. ${ }^{151}$ Two of the nurses who treated Mr. Duncan in the final stages of his illness became infected and, after treatment at other institutions, completely recovered. ${ }^{152}$

In addition to those quarantined in Texas, 164 contacts of one of the nurses who travelled to Akron, Ohio, were asked to monitor their temperature and symptoms for the twenty-one-day incubation period. Of those, twenty contacts who were within a three-foot radius of the patient and in the same enclosed space for more than an hour were

149 Amy E. Nutt, Family of Texas Ebola Patient Ordered to Stay Home, Comply with Blood Tests, WASH. Post, Oct. 2, 2014, archived at http://perma.cc/QN9D-R8LM.

150 See CDC, supra note 146, at 5-6.

151 Michelle S. Chevalier, Ebola Virus Disease Cluster in the United States - Dallas County, Texas 2014, 63 Morbidity \& MorTality WEEKLY REP. 1087 (2014); Manny Fernandez, Dallas Closes the Door on Its Ebola Scare, N.Y. TIMES, Nov. 8, 2014, at A10, archived at http://perma.cc/94DN-5ZNK.

152 Alan Blinder, Amber Joy Vinson, Dallas Nurse Treated for Ebola, Is Released from Hospital, N.Y. TimEs (Oct. 28, 2014), available at http://www.nytimes.com/2014/10/29/us/ebola-outbreak-dallas-nurseamber-joy-vinson.html?_r=0, archived at http://perma.cc/23R4-FH77. 
actively monitored through twice daily temperature checks (once in person and once by phone), and three individuals with likely skin-to-skin contact with the patient were placed in quarantine. ${ }^{153}$ Such measures, clearly intended to allay public fears, had the opposite effect and undoubtedly contributed to panic.

The entire, unfortunate episode at Texas Health Presbyterian Hospital in Dallas, where Mr. Duncan was treated, could and should have been prevented. It was unrealistic for the CDC to expect that every hospital would be able to treat Ebola patients without endangering the medical and nursing staff. ${ }^{154}$ Eventually, the CDC changed its policy and certified thirty-five hospitals nationwide as being prepared to treat Ebola patients, and most of these hospitals are located within a short distance of the airports where passengers land who originated in West Africa and connected in Europe. ${ }^{155}$

At the numerous public health briefings about Ebola public health officials mentioned that the illness can be spread only when there is direct contact with the bodily fluids of an infected individual. This statement is true, but imprecise and incomplete. First, although a wide range of bodily fluids may have detectable levels of virus within days after infection, without more, the statement gives the

153 Carolyn L. McCarty et al., Response to Importation of a Case of Ebola Virus Disease - Ohio, October 2014, 63 Morbidity \& MORTALITY WEEKLY REP. 1089 (2014).

154 Press Release, CDC, CDC's Surge Response to West African Ebola Outbreak (Aug. 6, 2014), available at http://www.cdc.gov/media/releases/2014/p0806-ebola.html, archived at http://perma.cc/F93D-Y6N4. Nevertheless, a survey by the Association for Professionals in Infection Control and Epidemiology indicated that only $6 \%$ of over 1000 infection control specialists surveyed October 1015,2014 , said that their hospitals were "well-prepared" to receive a patient with Ebola. APIC Ebola Readiness Poll, ASSOCIATION FOR Professionals in INFECTION CONTROL AND EPIDEMiology (Oct. 2014), http://www.apic.org/Resource_/TinyMceFileManager/Topicspecific/Ebola_Readiness_Poll_Results_FINAL.pdf.

155 U.S. Names 35 Ebola-Certified Hospitals, NBC News (Dec. 2, 2014) http://www.nbcnews.com/storyline/ebola-virus-outbreak/u-snames-35-ebola-certified-hospitals-n259896, archived at http://perma.cc/SEF8-Q5X6. 
impression that Ebola can be spread by having direct contact with any bodily fluid. In fact, contact must be with the highly infectious bodily fluid (i.e., vomit, diarrhea, or blood) of a seriously ill patient. Second, the statement fails to mention that there is no evidence of anyone becoming infected with Ebola in this epidemic without direct contact with the bodily fluid of an individual whose condition has progressed at least to the gastrointestinal phase of the illness. This phase occurs between three and ten days after the onset of symptoms. ${ }^{156}$

It should be remembered that the theory behind imposing quarantine is that some asymptomatic individuals may be infectious, and without quarantine they may expose others to the disease. This logic applies well with regard to many of the airborne diseases, such an influenza and SARS. It is not the case with Ebola, because an asymptomatic individual is not infectious and neither is a patient in the earliest stage of infection when the most noteworthy symptom is the onset of fever. Individuals become infectious only when the viral load in their bodily fluids is extremely high, 157 which occurs when the individuals become seriously ill and they release significant amounts of vomit, diarrhea, and blood. ${ }^{158}$ "We have very strong reason to believe that transmission occurs when the viral load in bodily fluids is high, on the order of millions of virions per microliter." 159 Of crucial importance, fever precedes the infectious stage; it does not indicate the infectious stage. ${ }^{160}$

156 See Daniel S. Chertow et al., Ebola Virus Disease in West Africa - Clinical Manifestations and Management, 371 New ENG. J. MED. 2054, 2054 (2014) (reporting that of more than 700 patients treated in Liberia "none that we were aware of had contracted disease from an infected contact during the early febrile [0-3 days from onset of symptoms] phase of illness" when the primary symptom is fever). See also Donald G. McNeil, Jr., Fewer Ebola Cases Go Unreported than Thought, Study Finds, N.Y. TIMES, Dec. 16, 2014, at A8, archived at http://perma.cc/L8MB-U4LK (reporting on study that transmission of Ebola occurs mostly within families, in hospitals, and at funerals).

157 Jeffrey M. Drazen et al., Ebola and Quarantine, 371 NEW ENG. J. MED. 2029 (2014).

158 Id. See Chertow et al., supra note 156.

159 Drazen, supra note 157, at 2029.

160 Id. 
Therefore, all individuals with possible Ebola exposure, but especially knowledgeable health care workers, who have any initial symptoms of Ebola infection, including fever, malaise, fatigue, and body aches, can be expected to seek hospital-based treatment immediately upon onset of any symptoms. Even at this stage they are not infectious. Individuals who seek treatment promptly can be safely isolated, and they stand the best chance of recovery. In the United States, other than two nurses who treated Mr. Duncan in Dallas, not a single contact of an Ebola patient became infected, including Mr. Duncan's relatives who lived with him in a small apartment after he displayed symptoms of disease.

Notwithstanding any realistic risk of contagion from asymptomatic health care workers, some health care workers with possible Ebola exposure failed to limit their public contact during the twenty-one day period after their last known exposure. This conduct contributed to substantial public anxiety in the United States. Although there was no risk of transmission while they were asymptomatic or until days later if they became symptomatic, these brave and selfless health care workers still had an obligation to help prevent the spread of panic. The situation could have been easily averted through selfimposed social distancing and by simply maintaining a more private lifestyle until the end of the incubation period. It is an interesting question of when scientifically unnecessary measures are appropriate to quell irrational public fears or when doing so "out of an abundance of caution" makes matters worse. In retrospect, a modest level of self-restraint would likely have preempted the irrational overreactions by some state and local governments.

Perhaps in response to some highly publicized incidents of public contacts by possibly exposed health care workers, as well as to preempt additional actions at the state level, the CDC revised its guidance for monitoring of persons with Ebola exposure to permit more individualized assessments of risk and more active surveillance of individuals with various degrees of risk. ${ }^{161}$ The $\mathrm{CDC}$ 's revision of its

161 CDC, supra note 146. 
guidance, however, by following more aggressive state policies, may have increased doubts about the adequacy of CDC's initial recommendations, thereby seeming to confirm the wisdom of the expanded quarantine measures imposed by some state governments. ${ }^{162}$

Deciding whether quarantine is necessary and, if so, determining the appropriate length of quarantine, are only the first steps in tailoring quarantine to the specific public health conditions. Additional considerations include the type of quarantine (individual or area-wide), whether quarantine should be voluntary or mandatory, how many individuals should be quarantined, the criteria for inclusion or exclusion, and the appropriate locations for quarantine. The overall goal should be to adopt the least burdensome means necessary to accomplish the desired public health objective. Using narrowly tailored public health measures also leads to greater public support for the entire range of public health interventions needed in an epidemic. ${ }^{163}$

Quarantine planning should focus on the totality of effects on individuals and society, not merely on the projected effects on infection rates. ${ }^{164}$ There is an important social element to the means chosen to implement quarantine. For example, in China, during the SARS outbreak, the level of compliance with orders directing individuals into quarantine at government facilities was lower than for quarantine at home because many people did not want to abandon their pets. 165 Thus, proportionality, minimal infringement on liberty, and consideration of the lifestyles of the individuals being placed in quarantine are crucial to promote compliance and public health.

In the United States, a commitment to proportionality increasingly has been reflected in public health

162 See Lisa Rosenbaum, Communicating Uncertainty - Ebola, Public Health, and the Scientific Process, 372 New EnG. J. Med. 7 (2015) (observing that ambiguous messages increase public panic).

163 See Sam Berger \& Jonathan D. Moreno, Public Trust, Public Health, and Public Safety: A Progressive Response to Bioterrorism, 4 HARV. L. \& POL'Y REV. 295, 316-17 (2010).

164 See Wendy E. Parmet, J.S. Mill and the American Law of Quarantine, 1 Pub. HeALth ETHICs 210, 210 (2008).

165 Rothstein et al., supra note 123 , at 25. 
preparedness documents, especially those dealing with influenza pandemics. For example, in 2007, the CDC proposed the Pandemic Severity Index (PSI), a classification scale for influenza pandemics. ${ }^{166}$ Based on the SaffirSimpson Hurricane Scale, the PSI contains five categories, ranging from 1 to 5 , which increase based on the severity of the case-fatality ratio (CFR).167 A category 1 event, such as seasonal influenza, has a CFR of less than $0.1 \% .168$ On the other extreme, a category 5 event, such as the 1918-1919 Spanish flu pandemic, has a CFR of $2.0 \%$ or higher. 169 Along with the new classification scale, the CDC also recommended the following four primary measures for slowing a pandemic: (1) isolation and treatment of people who have suspected or confirmed cases of pandemic influenza; (2) voluntary home quarantine of household contacts of those with suspected or confirmed pandemic influenza; (3) dismissing school classes and closing daycare centers; and (4) changing work schedules and canceling large public gatherings. ${ }^{170}$ By linking the intrusiveness of the response to the severity of the disease outbreak the PSI attempts to implement proportionality in the use of nonpharmaceutical disease-control measures. ${ }^{171}$

A similar commitment to proportionality is reflected in other public health laws and recommendations. For example, the Model State Emergency Health Powers Act requires that quarantine or isolation be imposed only if it is the "least restrictive alternative" available to control a public health emergency. ${ }^{172}$ As evidenced during the Ebola

166 DeP'T of Health and Human Servis., InTERIM Pre-Pandemic Planning Guidance: COMmunity STRATEgy For PANDEMic INFLUENZA Mitigation IN THE UNiTED STATES-EARLy, TARGETED, LAYERED UsE OF NONPHARMACEUTICAL INTERVENTIONS 31 (2007), available at http://www.cdc.gov/nonpharmaceutical-interventions/guidance, archived at http://perma.cc/9J3X-VAXF.

167 See id. at 31-32.

$168 \mathrm{Id}$. at 32.

169 Id.

170 Id. at 35.

171 See id.

172 The Model State Emergency Health Powers ACt § 604(b). 
outbreak, however, public and political pressures can lead to revision of previously adopted guidelines and policies.

\section{Humane Supportive Services}

Quarantine requires substantial logistical support, although the amount of support depends on the size and scope of the quarantine as well as the resources in place at the start of the quarantine. In quarantine at home, food, medicine, and other supplies and services must be provided to people who are unable to leave their homes. Public health officials need to be able to monitor the individuals in quarantine, a communication system must be established to connect the individuals in quarantine with health care providers, and a transportation plan is needed to take individuals who become ill to a hospital or other health care facility as soon as possible. In addition, clothing, bedding, and other personal items used by a patient placed in isolation may need to be removed and safely disposed of to prevent the infection of others, including individuals placed in quarantine at the same location. ${ }^{173}$

In monitoring the health status of the individuals in quarantine, public health officials need to strike a balance between public health and individual liberty. For example, in Singapore, during the SARS epidemic, all people quarantined at home were required to have a web camera connected at all times and to respond to random checks by the government to verify their presence at home. ${ }^{174}$ They also were required to check and record their temperatures twice a day, on camera if so directed. ${ }^{175}$ It is unlikely that such prescriptive and intrusive measures would be as well tolerated in the United States as they were in Singapore. ${ }^{176}$ Similarly, in the poor West African countries affected by

173 See Greg Botelho \& Michael Martinez, Frustrated Woman Quarantined With Sheets, Towels Soiled by Ebola Patient, CNN.COM, Oct. 2, 2014, archived at http://perma.cc/AVR5-W4EV.

174 Rothstein et al., supra note 123 , at 89.

175 Id.

176 See id. at 131. 
Ebola, the use of a web camera is, obviously, out of the question.

Providing humane supportive services to individuals in quarantine is labor-intensive, but the available supply of service providers may be curtailed by illness, death, quarantine, or refusal to report to work. 177 Providing humane supportive services is also more complicated in a pluralistic and heterogeneous society, such as the United States, than in more homogeneous Asian countries, such as those affected by SARS. 178 Among the vulnerable populations that might be affected to a greater extent by quarantine are individuals with disabilities, elderly persons, pregnant women, children, prisoners, economically disadvantaged minorities, people with mental illness or mental retardation, and individuals with language barriers. ${ }^{179}$ Even beyond these groups, a broad quarantine is likely to involve large numbers of individuals with diverse lifestyles. For example, dietary restrictions based on religion, culture, and health conditions ${ }^{180}$ mean that a standard food package for home delivery will not be sufficient for diverse individuals in quarantine. Nongovernmental organizations, such as the Red Cross, and governmental social service agencies need to coordinate their efforts and consider the special needs of people in quarantine. ${ }^{181}$

Other populations in quarantine raise additional logistical and policy challenges. If a home-based quarantine is adopted, alternate facilities will be needed for people without homes in the quarantine area, such as students, visitors, transients, and homeless people. Government officials will need to decide whether to ignore the lawbreaking status of undocumented aliens, criminal fugitives, and other individuals to encourage them to enter

177 See McNeil, supra note 35.

178 See Rothstein et al., supra note 123, at 26.

179 Sharona Hoffman, Preparing for Disaster: Protecting the Most Vulnerable in Emergencies, 42 U.C. DAVIS L. REV. 1491, 1499 (2009).

180 See generally Dennis P. Andrulis et al., Preparing Racially and Ethnically Diverse Communities for Public Health Emergencies, 26 HEALTH AFFAIRS 1269, 1269 (2007).

181 Rothstein et al., supra note 123 , at 138. 
quarantine rather than possibly spread disease. Immunity from arrest and prosecution were among the measures adopted by Singapore during the SARS outbreak. ${ }^{182}$

The quarantine of individuals addicted to illicit drugs poses another policy challenge. A simple admonition by public health officials or even a judicial order to stay at home is unlikely to be obeyed by individuals with a drug addiction, 183 and home delivery of illicit drugs by the government is unlikely to take place for numerous political and logistical reasons. It would be lawful for police to arrest and jail suspected drug addicts for the duration of the quarantine period, but only after they violated a quarantine order.

The question of what measures are appropriate for the government to take when there is noncompliance with mandatory quarantine applies to all individuals. Once again, it is a matter of proportionality. In particular, guidelines need to be developed for law enforcement personnel who observe individuals violating quarantine. The options for police are to ignore, warn, fine, or arrest and re-quarantine lawbreakers. During the SARS epidemic, many police officers that lacked training in infection control and personal protective equipment were reluctant to have close contact with individuals who violated quarantine because they were concerned about their own health. In Singapore, anyone violating quarantine had an electric tag put on their leg so they could be monitored. ${ }^{184}$

During the early days of the Ebola epidemic police initially failed to enforce quarantine provisions. ${ }^{185}$ More aggressive enforcement of the area-wide quarantine in the seaside slum of West Point, in Liberia's capital of Monrovia, led to a violent response. ${ }^{186}$ In Dallas, police were stationed outside the apartment where relatives of Thomas Eric Duncan were quarantined to ensure that they did not

\footnotetext{
182 Id. at 137.

183 Id.

184 See Rothstein, supra note 123, at 25.

185 See Nossiter, supra note 34.

186 See notes 222-248 infra and accompanying text.
} 
leave. ${ }^{187}$ Similarly, Kaci Wilcox, an asymptomatic nurse returning from West Africa who was placed in quarantine after a single elevated temperature reading, was under constant surveillance by state police when she left her home. ${ }^{188}$

The financial effect on individuals in quarantine is also an important concern. During the SARS epidemic all of the affected countries realized that they needed to enact legislation prohibiting discrimination in employment against individuals in quarantine (and guaranteeing their reemployment) and to supply quarantined individuals with some form of income replacement. Without such protections many low-income and self-employed persons who were asymptomatic would feel compelled to violate quarantine and go to work. Unfortunately, few, if any, comparable legal protections currently exist in the United States, ${ }^{189}$ and it is questionable how rapidly such legislation could or would be enacted at either the federal or state level. 190

Providing humane supportive services is a government's moral obligation in a public health emergency. Individuals relinquish a degree of liberty in exchange for the government's actions to preserve public health. The provision of humane supportive services in a public health

187 Kevin Sack \& Manny Fernandez, Delay in Dallas Ebola Cleanup as Workers Balk at Task, N.Y. TIMES, Oct. 2, 2014, at A1, A14, archived at http://perma.cc/HHQ8-KGGR.

188 Robert Gatter, Can States Force People into Quarantine?, HERE \& Now-WBUR, (Oct. 30, 2014) available at http://hereandnow.wbur.org/2014/10/30/hickox-maine-quarantine.

189 Mark A. Rothstein \& Meghan K. Talbott, Job Security and Income Replacement for Individuals in Quarantine: The Need for Legislation, 10 J. HEALTH CARE L. \& POL'Y 239, 243-44 (2007); accord Mark A. Rothstein \& Meghan K. Talbott, Encouraging Compliance with Quarantine: A Proposal to Provide Job Security and Income Replacement, 97 AM. J. Public Health S49, S49-S52 (2007). See also Mark A. Rothstein, Ebola, Quarantine, and the Law, 45 HASTINGS CTR. REP. No. 1, at 5 (2015).

190 New York City, however, announced that it was offering job protection and financial guarantees to health care workers traveling to West Africa to treat Ebola patients. Marc Santora \& Anemona Hartocollis, In New York, Protections Offered for Medical Workers Joining Ebola Fight, N.Y. TIMES, Oct. 31, 2014, at A23, archived at http://perma.cc/PC6D-Q5TW. 
emergency furthers the ethical principles of beneficence, justice, respect for persons, and social solidarity. Furthermore, providing humane supportive services also reaffirms the importance of dignity and human rights during times of peril, thereby helping to preserve the social fabric of society that will emerge after the outbreak is contained. Internationally, the Siracusa Principles provide that when a state acts in an emergency it must still respect human dignity and freedom, such as by not acting arbitrarily or discriminatorily and using the least restrictive means. ${ }^{191}$ Similarly, the World Health Organization's (WHO) Global Alert and Response Guiding Principles for International Outbreak Alert and Response includes the following: "All Network responses will proceed with full respect for ethical standards, human rights, national and local laws, cultural sensitivities and traditions."192

\section{Public Justification}

The public's willingness to comply with public health interventions to combat infectious disease outbreaks lessens the need for governmentally ordered coercive measures and enforcement actions directed at individuals who are noncompliant. Among other things, public support requires the government to act with transparency, due process, and fairness. ${ }^{193}$ The decision-making process used by public health officials and government leaders should be open, at least to the extent that the rationale for official action is clearly explained to the public. Decision makers should marshal the best available scientific evidence and expert opinion on the need for quarantine and then disclose the

191 U.N. ECON. \& Soc. CounCIL, Status of the International Covenants on Human Rights, U.N. Doc. E/CN.4/1985/4 (Sept. 28, 1984).

192 WoRld HEalth ORganization, Global Alert and Response, Guiding Principles for International Outbreak Alert and Response, www.who.int/csr/outbreaknetwork/guidingprinciples/en/, archived at http://perma.cc/99HV-4R79.

193 MaRgareT P. BATTIN ET AL., The PATIENT AS Victim AND VeCtor: Ethics AND InfeCtious Disease 385-401 (2009); Gostin \& Berkman, supra note 47 , at 170-72. 
information in a timely and understandable manner. 194 Good communication with the public may improve voluntary compliance and obviate the need for enforcement. 195

In the United States, perhaps the most challenging aspect of public justification would involve convincing individuals to ignore their self-interest in personal liberty to help promote the common good.196 Quarantine demands self-sacrifice to benefit society, but America's public ethos of libertarianism has translated into a historical and pervasive distrust of government, with a strong preference for selfreliance and independence. ${ }^{197}$ Americans are more likely to view health problems as individual rather than community challenges. 198 Furthermore, some Americans can be expected to resist any government-mandated confinement if they fail to apprehend a direct benefit to themselves or they believe the burden of complying with quarantine would be too great. 199 This would force public health officials to obtain court orders to enforce the public health edicts. Although legal challenges of government actions can be viewed as the price for living in a free society governed by the rule of law, excessive litigation during a public health emergency may not be the optimum use of government, including public health, resources.

In contrast with the United States, the jurisdictions most affected by SARS in Asia (China, Hong Kong, Singapore, Taiwan, and Vietnam), as well as Canada, are known for more communitarian values. Yet, the responses of individuals in these countries varied during the SARS

$194 \mathrm{Yu}$ Wang, The H7N9 Influenza Virus in China-Changes Since SARS, 368 N. ENG. J. MED. 2348, 2348 (2013).

195 Maxwell J. Smith et al., Restrictive Measures in an Influenza Pandemic: A Qualitative Study of Public Perspectives, CAN. J. PuB. HEALTH at e348, e350-51 (July 18, 2012).

196 Matthew K. Wynia, Ethics and Public Health Emergencies: Restrictions on Liberty, AM. J. Bioethics 1, 3 (Feb. 2007).

197 Mark A. Rothstein, Are Traditional Public Health Strategies Consistent with Contemporary American Values?, 77 TEMP. L. REV. 175, 177 (2004).

198 See id. at 190.

199 See id. at 191. 
epidemic. In Toronto, there were about 30,000 people in quarantine, and in only twenty-seven cases was a quarantine order required. ${ }^{200}$ In China, however, despite generally high rates of compliance with various public health measures, tens of thousands of individuals fled from areas when they learned of an impending area-wide quarantine, thereby possibly spreading the epidemic. ${ }^{201} \mathrm{~A}$ post-SARS survey of residents of Hong Kong, Singapore, Taiwan, and the United States indicated substantial concerns about compulsory quarantine, including becoming infected in group quarantine, losing income, and being unable to communicate with family members. ${ }^{202}$ Because rates of noncompliance with quarantine for pandemic influenza or another highly communicable disease could be significant, ${ }^{203}$ clear public justification and logistical support for individuals in quarantine are essential. ${ }^{204}$

Justice is a primary ethical consideration in quarantine. 205 The burdens and benefits of any public health intervention, especially quarantine, should be equitable in design, application, and effect.206 Regrettably, there is a long history in the United States of discriminatory imposition of quarantine, often based on xenophobia and racism. For example, in 1892, after four cases of typhoid fever were discovered in a New York City tenement house among recent Russian Jewish immigrants who arrived on the ship Massilia, city health officials ordered the quarantine of 1200 largely unexposed people who happened to live near the infected passengers. ${ }^{207}$

200 Rothstein et al., supra note 123 , at 58.

201 Id.

202 Robert J. Blendon et al., Attitudes Toward the Use of Quarantine in a Public Health Emergency in Four Countries, 25 HEALTH AFFAIRS W15, W15-W25 (2006).

203 Jason W. Sapsin et al., $S A R S$ and International Legal Preparedness, 77 TEMP. L. REV. 155, 164 (2004).

204 Id. at 165.

205 See generally Daniel Markovits, Quarantines and Distributive Justice, 33 J.L. MED. \& ETHICs 323 (2005).

206 Council on Ethical \& Judicial Affairs, The Use of Quarantine and Isolation as Public Health Interventions, 123 PUB. HEALTH REP. 3 (2008).

207 MARKEL, supra note 8, at 16. 
Similarly, in 1900, to combat the spread of bubonic plague, San Francisco enacted an ordinance requiring all Chinese residents to receive plague vaccines, and those failing to do so were prohibited from leaving the city. ${ }^{208}$ Because the law expressly applied only to Chinese residents, it was declared unconstitutional as violating the Equal Protection Clause of the Fourteenth Amendment. ${ }^{209}$

Although these infamous incidents are over 100 years old, discrimination in the application of public health policies has taken place in recent times as well. During the SARS epidemic there were widespread reports of discrimination against Asians in several American cities. In one incident, in Vineland, New Jersey, a dance troupe from Chinatown in New York City was turned away from its annual performances at two middle schools because of fear of SARS. One school even sprayed the hallways with the disinfectant Lysol $^{\circledR}$ after the troupe left. ${ }^{210}$ An unmistakable lesson learned from the aftermath of Hurricane Katrina in 2005 is that a public health emergency often adversely affects socially and economically vulnerable individuals, and it has the potential to exacerbate existing social inequalities. ${ }^{211}$

Similar disparities existed in the response to the 2009 H1N1 influenza epidemic. ${ }^{212}$ Because the outbreak arose in Mexico and spread to the United States, there was substantial mistreatment of and discrimination against Latinos, including bullying, stigmatization by health care providers, shops telling Mexicans to keep out, and a school denying admission to children uninfected with $\mathrm{H} 1 \mathrm{~N} 1$,

208 Wong Wai v. Williamson, 103 F. 1, 2-3 (C.C.N.D. Cal. 1900); Jew Ho v. Williamson, 103 F. 10, 11-12 (C.C.N.D. Cal. 1900).

209 Wong Wai, 103 F. at 6; Jew Ho, 103 F. at 23-24.

210 Rothstein et al., supra note 123, at 140.

211 See Madison Powers \& Ruth Faden, Social Justice: The Moral Foundations of Public Health and Health Policy 3 (2006); Lori Uscher-Pines et al., Planning for an Influenza Pandemic: Social Justice and Disadvantaged Groups, 37 Hastings CtR. REP. 32, 32 (2007).

212 Debra DeBruin et al., Social Justice in Pandemic Preparedness, 102 AM. J. PUb. HeALth 586, 586 (2012). 
simply because the children had recently emigrated from Mexico. ${ }^{213}$

Predictably, during the Ebola epidemic, there were many incidents of irrational fear and discrimination. For example, in New Jersey, two students from Rwanda, which had no Ebola cases and is 2800 miles from the affected countries in West Africa, were told to stay home. ${ }^{214}$ Similarly, a third grader in Connecticut was barred from school because she had attended a family wedding in Nigeria, which the WHO had declared Ebola-free. ${ }^{215}$ In perhaps the most extreme example of irrational fear, a formerly thriving bridal shop in Akron, Ohio, went out of business because, after it was visited by a presymtomatic, Ebola-infected nurse from Dallas, it became known as "the Ebola store."216

Panic, discrimination, and ostracism have not been limited to the United States. In Sierra Leone, the fortunate few who survived Ebola became literally "untouchable" in many communities. 217 In addition, thousands of children who were orphaned by Ebola in Guinea, Liberia, and Sierra Leone were stigmatized or abandoned by members of their extended family due to irrational fear. ${ }^{218}$ According to the United Nations Children's Fund (UNICEF), there may be 10,000 Ebola orphans in West Africa, many of them languishing in group homes without prospects for

213 Monica Schoch-Spana et al., Stigma, Health Disparities, and the 2009 H1N1 Influenza Pandemic: How to Protect Latino Farmworkers in Future Health Emergencies, 8 BIOSECURITY \& BIOTERRORISM: Biodefense Strategy, PRACTiCe, AND Science 243, 247 (2010).

214 Nicholas Kristof, How to Defeat Ebola, N.Y. TIMES, Oct. 23, 2014, at A35, archived at http://perma.cc/7FDS-XZCB.

215 Child Barred from School; Father Sues, N.Y. Times, Oct. 29, 2014, at A12, archived at http://perma.cc/W7C4-8L8A.

216 Mitch Smith, Stigma of Ebola Customer Is Too Much for Bridal Shop, N.Y. TIMES, Jan. 9, 2015, at A13, http://perma.cc/9CQX-8XUN.

217 Adam Nossiter, Surviving Ebola, but Untouchable Back Home, N.Y. TiMES, Aug. 19, 2014, at A1, http://perma.cc/84M3-BLBX.

218 Faith Karimi, Thousands of Children Orphaned by Ebola Abandoned, Stigmatized, CNN.COM, archived at http://perma.cc/M9UQ$8 \mathrm{EF}$. 
adoption. ${ }^{219}$ Although there have been some efforts to provide support services 220 and to reintegrate Ebola survivors into their communities, ${ }^{221}$ these efforts have been on a relatively small scale and their effectiveness has not been clearly established.

The final aspect of public justification involves the important relations among the government, the media (broadly defined), and the public. The 2009 H1N1 influenza epidemic provides an instructive case study, as it featured the convergence of a new presidential administration in Washington, a weak American economy, and a highly skeptical public whose fears and suspicions were stoked by cable news, social media, and a $24 / 7$ news cycle. When the H1N1 influenza strain emerged in 2009, public health officials were quite concerned about a possible 1918-1919type pandemic, inasmuch as the broad H1N1 influenza strain was the same. Yet, there were few hard facts or confident predictions available. In attempting to be candid and transparent, however, government admissions of uncertainty seemed to undermine public confidence rather than enhance it. "The result was to heighten public distrust and suspicion of both the government's credibility and its capacity to provide accurate information."222 Political party affiliation was closely associated not only with trust in the government's pronouncements, but with the likelihood of taking the H1N1 vaccine. Overall, although 80 to 90 million Americans received the vaccine, about 70 million doses went unused and had to be destroyed. ${ }^{223}$ In the future, public health officials should not only make the scientific case for

219 Jeffrey Gettleman, An Ebola Orphan's Plea: "Do You Want Me?" N.Y. TIMES, Dec. 14, 2014, at A1, archived at http://perma.cc/C2XWSHED.

220 Seung Hee Lee-Kwan et al., Support Services for Survivors of Ebola Virus Disease - Sierra Leone, 2014, 63 MorBIDITY \& MorTALITY WEEKLY REP. 1205 (2014).

221 M. Allison Arwady et al., Reintegration of Ebola Survivors into Their Communities - Firestone District, Liberia, 2014, 63 MoRBIDITY \& MORTALITY WEEKLY REP. 1207 (2014).

222 Leslie E. Gerwin, The Challenge of Providing the Public with Actionable Information During a Pandemic, 40 J.L. MED. \& ETHICs 630, 642 (2012).

$223 I d$. at 648 . 
public health action, but they must confront the reality that politicization of public health may undermine public support for any proposed action. ${ }^{224}$

\section{VI.EBOLA QUARANTINE IN LIBERIA}

Although various forms of quarantine were used throughout West Africa in attempting to control the spread of Ebola, the quarantine imposed in Liberia is the most troubling and therefore the most instructive. Liberia, a country of 4.3 million, had only fifty-one physicians before the Ebola epidemic. ${ }^{225}$ The disease outbreak decimated the existing health care infrastructure and personnel. ${ }^{226}$ Because most Ebola patients were cared for at home by relatives and friends without adequate personal protective equipment, the disease often spread to the caregivers. Burial rites, in which family members washed the highly infectious bodies of their loved ones, also caused the spread of infection. ${ }^{227}$

On August 24, 2014, the government of Liberia imposed an area quarantine or cordon sanitaire on the West Point section of the capital city, Monrovia. ${ }^{228}$ West Point, a "sprawling slum," 229 is the home to 60,000 to 120,000 people, who live "crammed into crumbling shacks." 230 The quarantine period of twenty-one days was intended to cover the incubation period for the virus. Unsurprisingly, the

224 During the Ebola epidemic the public also exhibited a distrust of "experts," whose motives and reasoning were widely called into question. Richard Pérez-Peña, Alarmed by Ebola, Public Isn't Calmed by "Experts Say," N.Y. Times, Nov. 1, 2014, at A19, archived at http://perma.cc/V7YS-UCUB.

225 Annette Rid \& Ezekiel J. Emanuel, Why Should High-Income Countries Help Combat Ebola?, 312 JAMA 1297 (2014).

226 Onishi, supra note 138.

227 Nick Cumming-Bruce, W.H.O. Issues New Guidelines on Safely Burying Ebola Victims, N.Y. TIMES, Nov. 8, 2014, at A4, archived at http://perma.cc/46UN-P4YV.

228 Onishi, supra note 37.

229 McNeil, supra note 35.

230 Norimitsu Onishi, As Ebola Grips City, Quarantine Adds to Chaos, N.Y. TIMES, Aug. 29, 2014, at A1, archived at http://perma.cc/8WQ2-KMPT. 
quarantine proved to be a disaster, and it was ended after ten turbulent days. ${ }^{231}$ The experience in Liberia serves as a case study of the need to apply the four ethical considerations discussed in the previous section of this article.

To begin with, it was highly questionable whether the first consideration, "necessity, effectiveness, and scientific rationale," was even remotely satisfied. Liberia's President, Ellen Johnson Sirleaf, who received the Nobel Peace Prize in 2011, ${ }^{232}$ reportedly rejected the recommendation of international experts and her own public health officials, and imposed the quarantine at the urging of the army. ${ }^{233}$ In theory, if the infection could be localized and contained, then it could "burn out" before spreading to the rest of Monrovia and beyond.

This rationale was unsupported by the conditions of the Ebola epidemic, however, as the virus was not localized in West Point. Furthermore, because people in West Point live so close together and formed angry crowds to protest the quarantine, the increase in close human contact actually increased the risk of transmission. ${ }^{234}$ At the start of the quarantine, Dr. Martin Cetron of the CDC commented that the quarantine "has a lot of potential to go poorly if it's not done with an ethical approach. Just letting the disease burn out and considering it [the deaths] the price of controlling it [Ebola] - we don't live in that era anymore."235

231 Norimitsu Onishi, Quarantine for Ebola Lifted in Liberia Slum, N.Y. Times, Aug. 30, 2014, at A4, archived at http://perma.cc/SMD9RST7.

232 As the first woman leader of an African nation, she was honored for her contributions to freedom and equality, Ellen Johnson Sirleaf Biographical,

NOBELPRIZE.ORG, http://www.nobelprize.org/nobel_prizes/peace/laureates/2011/johnson_si rleaf-bio.html, archived at http://perma.cc/ZNP9-MF6R (last visited Feb. 17, 2015).

233 Onishi, supra note 231.

234 Ebola is spread by contact with infected body fluids, such as blood, vomit, and diarrhea. See World HeAlth ORGANiZATION, supra note 5 .

$235 \mathrm{McNeil}$, supra note 35. 
According to Gregory Hartl of the WHO, during a cordon sanitaire "human rights have to be respected." 236

Imposing a cordon sanitaire on such a heavily populated area also fails to satisfy the second consideration of "proportionality and least infringement." The Liberian government failed to use less drastic means of social distancing or other measures to enlist the support of residents in West Point or elsewhere in Liberia. Furthermore, with the twenty-one day period of infectivity, the confinement of such a large population in a small area was almost certain to cause hardship and panic.

The lack of "humane supportive services," the third ethical consideration, doomed the effort from the start. Almost immediately after the quarantine was imposed, essential goods, such as food and water, doubled in price. ${ }^{237}$ One resident remarked at the prospect of the twenty-one day quarantine, "I wouldn't die of Ebola but of hunger."238 Many residents worked outside of West Point, and they were left with no means of income. There were few health services available for the individuals with malaria and other diseases, and there was little or no medical surveillance to detect new Ebola cases and to isolate those individuals. Even before the quarantine order, highly infectious dead bodies remained in the streets for hours, sometimes days. ${ }^{239}$

Perhaps the worst mistake of the cordon sanitaire was the lack of "public justification," the fourth essential ethical consideration. West Point was the site of an earlier riot in which residents raided an Ebola screening center, accusing the government of bringing sick people from all over Monrovia into their neighborhood. ${ }^{240}$ The lack of public health education was a major contributing factor to spreading the disease from the start of the Ebola outbreak, as many individuals did not understand how Ebola was

236 Id.

237 Onishi, supra note 230.

238 Onishi, supra note 231.

239 Liberian Soldiers Seal Slum to Halt Ebola, CNN.COM, Aug. 20, 2014, archived at http://perma.cc/HJG4-QUCN.

240 Id. 
transmitted and therefore failed to take steps for their own protection.

With no public consultation or input from affected citizens, the Liberian army suddenly unfurled razor wire to enclose the area. ${ }^{241}$ The army and police enforced the restrictions with force. When angry young men hurled rocks and stormed barbed-wire barricades, trying to break out, the police responded by firing live bullets. ${ }^{242}$ A fifteen year-old boy who was going to buy tea and bread for his aunt was struck by stray bullets and killed. ${ }^{243}$ Other residents of West Point attempted to bribe soldiers to let them out. ${ }^{244}$

Unlike some of the other countries affected by Ebola, such as Nigeria ${ }^{245}$ and the Democratic Republic of Congo, ${ }^{246}$

241 Onishi, supra note 231.

242 Onishi, supra note 230.

243 Id.; Norimitsu Onishi, Inquiry Faults Liberia Force that Fired on Protesters, N.Y. TIMES, Nov. 4, 2014, at A4, archived at http://perma.cc/4VL8-AZK4.

244 Onishi, supra note 230.

245 In contrast to Liberia, its wealthier neighbor, Nigeria, was able to respond quickly and effectively to its initial Ebola cases and limited the death toll to eight. It was critical to stop Ebola before it spread, because Nigeria is Africa's most populous country (177 million, including 21 million in the capital city of Lagos). Among the resources brought to bear by Nigeria were an existing disease operations center, health educators to inform the public, health workers trained in epidemiology to do contact tracing, coordination with nongovernmental entities such as Doctors Without Borders and the International Committee for the Red Cross, isolation rooms at hospitals, air conditioning in hospitals that permitted people wearing personal protective equipment to work longer shifts, laboratories that could perform Ebola testing in a matter of hours, and experience in treating Lassa fever, cholera, and other infectious diseases. Donald G. McNeil, Jr., Nigeria's Actions Seem to Contain Ebola Outbreak, N.Y. TIMEs, Oct. 1, 2014, at A1, A12, archived at http://perma.cc/JM6K-X6EV; See also Bashir Adigun \& Maria Cheng, WHO: Nigeria's Ebola Outbreak IS Officially Over, NEWSOBSERVER.com (Oct. 20, 2014), http://abcnews.go.com/Health/wireStory/nigerias-ebola-outbreakofficially-26316066, archived at http://perma.cc/8PT7-WG95; Denise Grady, Better Staffing Seen as Crucial to Close Ebola Treatment Gap, N.Y. Times, Nov. 1, 2014, at A1, archived at http://perma.cc/7QQEW7VM; Betsy McKay \& Drew Hinshaw, Lack of Qualified Staff in Africa Hurts Effort, WALL ST. J., Oct. 3, 2014, at A6, available at 
Liberia lacked the resources to combat the epidemic. In addition to an expanded health care infrastructure, 247 Liberia needed public education about Ebola; trust building; 248 transparency and communication about public health countermeasures; training, personal protective equipment, and hazard pay for health care workers; and precautions against further transmission. ${ }^{249}$ Most of all, it needed more health care workers; if not from Africa, then from overseas. ${ }^{250}$ Instead, the most vulnerable citizens in the most vulnerable part of the capital city were trapped by the area quarantine. Many residents believed they were confined to die. By contrast, North of Monrovia, soldiers

http://www.wsj.com/articles/lack-of-qualified-staff-hurts-ebola-fight-inafrica-1412293011, archived at http://perma.cc/F4DB-RXMW.

246 The Democratic Republic of Congo (DRC), formerly Zaire, is the place where the first documented Ebola outbreak occurred in 1976. During the most recent Ebola epidemic there were sixty-six cases and forty-nine deaths in the DRC. After a three-month outbreak, the WHO has declared the country to be Ebola-free. It has been asserted that the relatively mild outbreak in the DRC can be attributed to experience dealing with Ebola (it was the seventh outbreak in the last 40 years), the remoteness of the country prevented large-scale spread of contagion, and health care workers knew how to diagnose Ebola. Maggie Fox, $A$ Tale of Two Outbreaks: Why Congo Conquered Ebola, NBC NEws (Nov. 24, 2014), http://www.nbcnews.com/storyline/ebola-virus-outbreak/taletwo-outbreaks-why-congo-conquered-ebola-n253911, archived at http://perma.cc/47RH-JMQ7.

247 Andrew S. Boozary et al., The Ebola Outbreak, Fragile Health Systems, and Quality as a Cure, 312 JAMA 1859 (2014).

248 According to Dr. Emmanuel d'Harcourt, Senior Health Director for the International Rescue Committee: "It's trust more than anything that's needed right now. . . . If people don't trust what their governments, the WHO and aid workers are telling them about how not to spread Ebola, it will continue to be spread." Maggie Fox, Can Ebola's Deadly Rampage in Africa Be Stopped in 2015?, NBC NEws (Dec. 23, 2014), http://www.nbcnews.com/storyline/ebola-virus-outbreak/canebolas-deadly-rampage-africa-be-stopped-2015-n271001, archived at http://perma.cc/QE7A-E5MX.

249 Almea Matanock et al., Ebola Virus Disease Cases Among Health Care Workers Not Working in Ebola Treatment Units - Liberia, June-August, 2014 , 63 MorBIDITY \& MoRTAlity WeEKLY ReP. 1077 (2014).

250 Grady, supra note 245; Betsy McKay \& Drew Hinshaw, Lack of Qualified Staff in Africa Hurts Effort, WALL ST. J., Oct. 3, 2014, at A6, archived at http://perma.cc/6FVK-PVNP. 
checked the credentials and temperature of those trying to go in or out. ${ }^{251}$ Only in West Point were the people kept separated from the rest of the population by razor wire and bullets.

By March 2015, the last Ebola patient had been released from a treatment center, and life in Liberia was starting to return to normal. President Ellen Johnson Sirleaf, in an interview with the editorial board of the New York Times, admitted that the West Point quarantine was a terrible mistake.

It did not take long to know that it did not work. It created more tension in the society. . . . We went into a security approach. We put the army there. We put the security people there. We closed the borders. . . . Now I know that people's ownership, community participation, works better in a case like this. I think that experience will stay with us. ${ }^{252}$

\section{CONCLUSION}

Quarantine, one of the first tools of public health for the control of communicable diseases, remains a lawful and valuable public health strategy. Quarantine also raises in the starkest possible terms the fundamental ethical conflict of public health-the clash between individual and population rights and interests. In the United States, personal liberty is greatly valued and protected by law, although the Supreme Court has long held that liberty may be restricted through "reasonable regulation" to protect the public health. ${ }^{253}$ Consequently, it will be a significant challenge for public officials and public health experts to convince large numbers of asymptomatic people of the necessity and moral imperative of their temporarily

251 McNeil, supra note 35.

252 Rick Gladstone, Liberian Leader Concedes Errors in Response to Ebola, N.Y. Times, March 12, 2015, at A6, archived at http://perma.cc/2JQR-PLPP.

253 Jacobson v. Massachusetts, 197 U.S. 11, 25 (1905). 
relinquishing a degree of their liberty for the possible benefit of the public's health.

The federal government has the constitutional authority under the Commerce Clause to impose quarantine to prevent the international and interstate spread of infection, and this responsibility has been delegated to the CDC. Nevertheless, the states maintain primary responsibility for public health, including quarantine. Many of the state quarantine laws were originally enacted in the early twentieth century. The anthrax attack in 2001 provided the impetus for updating these laws to modernize and streamline state public health emergency response. Although all of the states have updated their laws, at least to some extent, these efforts must be considered works in progress. Some of the model laws used as templates for modernization have been criticized for failing to include adequate protections for civil liberties and due process. Virtually all of the laws lack key ancillary measures needed for successful quarantine, such as prohibiting employment discrimination against individuals in quarantine and providing for temporary income replacement so that individuals will not be tempted to violate the quarantine and go to work. ${ }^{254}$

Because quarantine is one of the most intrusive and demanding of public health interventions, it tends to expose or magnify the vulnerabilities of a public health system. That is certainly the case with the 2014 Ebola outbreak. In West Africa, the lack of health care infrastructure, combined with extreme poverty, resulted in a widespread human tragedy. ${ }^{255}$ In the United States, due to its complex and decentralized public health system, communication, coordination, calm, and proportionate response quickly emerged as leading concerns when a few Ebola cases were diagnosed and treated.

254 See supra note 189 and accompanying text.

255 See Maggie Fox, Ebola Hurts More Than Sick: World Bank, NBC NEWs (Jan. 12, 2015), http://www.nbcnews.com/storyline/ebola-virusoutbreak/ebola-hurts-more-sick-world-bank-n284421, archived at http://perma.cc/R6Q6-SVUT. 
Quarantine procedures can only be as effective as a nation's overall public health system and its comprehensive approach to controlling an epidemic. Besides quarantine, isolation, public education, health care work force development and training, contact tracing, travel restrictions, medical surveillance, vaccine and medication development, clinical interventions, and other public health actions are important. This article has considered only one of the many important and complex aspects of a public health response to an epidemic. Indeed, in every affected country an epidemic such as the Ebola outbreak of 2014 represents a moral challenge on an individual and societal level. ${ }^{256}$

To maximize an effective response and to obtain public support for quarantine, public health officials contemplating, devising, or implementing a plan of action should be aware of the centrality of ethical criteria. In particular, four essential considerations for modern quarantine are the following: (1) necessity, effectiveness, and scientific rationale; (2) proportionality and least infringement; (3) humane supportive services; and (4) public justification. Thoughtful application of these considerations will increase the likelihood of a successful quarantine, thereby hastening the end of a deadly disease outbreak. Of equal importance, these ethical considerations are essential to maintaining the social fabric of a society during the period of quarantine and thereafter.

256 See Mark A. Rothstein, The Moral Challenge of Ebola, 104 AM. J. Pub. Health 6 (2015). 